\title{
Deep-well pumping in the Bangkok Plain and its influence on ground improvement development with surcharge and vertical drains
}

\author{
A. S. BALASUBRAMANIAM*, E. Y. N. OH*, M. W. BOLTON*, \\ D. T. BERGADO ${ }^{\dagger}$ and N. PHIENWEJ ${ }^{\dagger}$ \\ *School of Engineering, Griffith University Gold Coast Campus, Australia; ${ }^{\dagger}$ School of Civil \\ Engineering, Asian Institute of Technology, Bangkok, Thailand
}

The Bangkok subsoil that forms part of the larger Chao Phraya Plain consists of a broad basin filled with sedimentary soil deposits that form alternate layers of sand, gravel and clay. The depth of the bedrock is still undetermined, but its level in the Bangkok area is known to vary between $400 \mathrm{~m}$ and $1800 \mathrm{~m}$ deep. The aquifer system beneath the city area is very complex, and the deep-well pumping from the aquifers over the last 50 years or so has caused substantial piezometric drawdown in the upper soft and highly compressible clay layer. In this paper, the influence of the piezometric drawdown on the performance of vertical drains with surcharge on the upper clay layer is examined. Instrumented test embankments were built and the performance of large-diameter sand drains, sand wicks and prefabricated vertical drains was examined. A novel interpretation technique was adopted to evaluate the settlements from pore pressure dissipation and to compare with those measured directly from settlement measurements.

Keywords: Bangkok subsoil; ground improvement; subsidence

\section{Introduction}

It is interesting to look back on the lessons learnt from the development of ground improvement techniques with surcharge and vertical drains in Bangkok subsoils. The potential use of surcharge and vertical drains as a ground improvement technique was explored as early as 1966 (Eide, 1977) for its application in bridge approaches. A test section on the Bangkok-Siracha Highway was built and tested with $0.20 \mathrm{~m}$ diameter sand drains; the depth of the sand drains varied in steps from 4 to $13 \mathrm{~m}$. During construction, failure of the soft clay occurred in five locations, and the $2.2 \mathrm{~m}$ high embankment was furnished with $8 \mathrm{~m}$ wide berms to ensure stability. From the observed settlement of the test embankment, Eide (1977) concluded that the drained embankment section settled most to start with, but after one year the rate of settlement was almost the same, approximately $0.0025 \mathrm{~m}$ per

(GI 4202) Paper received 24 March 2002; last revised 31 March 2005; accepted 8 April 2005
Le sous-sol de Bangkok qui forme une partie de la plaine plus vaste de Chao Phraya est constitué d'un large bassin rempli de dépôts sédimentaires qui forment des couches alternées de sable, de gravier et d'argile. La profondeur du lit rocheux reste indéterminée mais on sait que son niveau dans la zone de Bangkok se situe entre $400 \mathrm{~m}$ et $1800 \mathrm{~m}$ de profondeur. Le système aquifère sous la ville est très complexe et un pompage à puits profonds au cours des $\mathbf{5 0}$ dernières années a causé une baisse substantielle du niveau piézométrique dans la couche argileuse supérieure molle et hautement compressible. Dans cet exposé, nous examinons l'influence de la baisse piézométrique sur la performance de drains verticaux surchargés sur la couche argileuse supérieure. Des berges de contrôle instrumentées ont été construites et la performance de drains de sable de gros diamètre, de mèches de sable et de drains verticaux préfabriqués a été étudiée. Nous avons adopté une technique d'interprétation innovante pour évaluer les tassements d'après la dissipation de la pression interstitielle et pour les mesures de tassement directes.

month on both the drained and undrained sections. The practical conclusion reached by Eide (1977) was that this type of drain and spacing would not serve the purpose in bridge approaches. However, Eide (1977) agreed that the results obtained might have been affected by other factors, such as slip failures, the remoulding effect from the installation of drains, the low permeability and greater secondary consolidation settlement of the soft clay.

A second attempt was made in 1975-1977, with the construction of a dockyard for the Royal Thai Navy, and a test embankment was built in order to evaluate the performance and suitability of sand drains (sand wick type) as a means to accelerate the consolidation of the soft clay. Without an understanding of the recharge effect due to the sand wicks on the piezometric drawdown, doubts were cast on the pore pressure measurements as revealed below the natural terrain in which the sand wick was installed, and this led to the installation of additional piezometers; finally there were a total of 166 piezometers monitoring the pore pressures below the clay surface. It was found that the installation of the sand wicks had recharged the area below 
the test embankment with and without drains, and erased the normal piezometric drawdown that normally existed in the Bangkok subsoils due to deep-well pumping, as can be seen in the area that was not influenced by the test embankment location installed with sand wick drains. This recharging effect was somehow not envisaged in the original planning and design of the test embankment. However, it gave valuable insights into the extensive deep-well pumping in the Bangkok Plain, and the piezometric drawdown that has resulted in the Bangkok subsoils as a consequence of this groundwater withdrawal.

In 1983, the most extensive sand drain studies were performed as part of the investigations related to the Second International Airport, which is currently under completion. The purpose of the trial tests was to ensure the effectiveness of using non-displacement types of sand drain for accelerating consolidation settlement of soft clay. Sand drains of minimum diameter $0.26 \mathrm{~m}$ were installed to a depth of $14.5 \mathrm{~m}$ by the water-jetting method. During this study, the feasibility of the use of vacuum drains was also investigated, but the idea was abandoned as several leaks developed and the vacuum was unable to be maintained.

However, additional knowledge gained was that a settlement of the order of $0.4 \mathrm{~m}$ was experienced over a period of 6 months after the installation of the sand blanket (only $0 \cdot 8 \mathrm{~m}$ thick) alone and prior to the use of surcharge fills. This observation has led to the interpretation of possible hydraulic connections between the sand drains and the first sand layer located at $25 \mathrm{~m}$ depth with a piezometric drawdown of $12 \mathrm{~m}(120 \mathrm{kPa})$.

The above experiences and the lessons learnt led to a rather cautious approach on the final studies carried out (for a two-year period from 1994 to 1995) for the construction of the runway and other structures at the Second Bangkok International Airport (SBIA) site. In this study, it was concluded that the use of prefabricated vertical drains (PVDs) and surcharge was the most suitable ground improvement technique. This paper describes the history of groundwater pumping in the Bangkok Plain, the accumulated piezometric drawdown, and its influence in the development of surcharge with PVDs as a suitable ground improvement technique.

\section{Bangkok subsoil conditions and the effect of deep-well pumping}

\section{Geology and hydrogeology of the Bangkok Plain}

Bangkok is situated on the floodplain and delta of the Chao Phraya River, which traverses the Lower Central Plain of Thailand. The clastic sediments overlying the basement complex are unconsolidated and semi-consolidated clay, sand and gravel ranging in age from Tertiary to Quaternary (see Fig. 1). Muktabhant et al. (1967) have described how the late Tertiary structural movements of the earth crust and the sequence of alluvial cycles were probably influenced by the formation of the depression of the Chao Phraya Basin. The subsequent marine sedimentation resulted in the unconsolidated deposition of the Bangkok subsoils. Also, according to Eide (1968), the overlying soft clay was deposited when the sea level rose for the second time after a period of recession. When the water level dropped below the ground surface, soft clay was exposed to physical and chemical weathering processes of alternating wetting and drying cycles, which eventually yielded the hard, shallow crust that covers the whole area of the Chao Phraya Plain.

Muktabhant et al. (1967) and Moh et al. (1969) have divided the subsurface soil conditions into four apparent layers. The top layer is a weathered zone of soft clay, which is dark brown in colour with variable thicknesses from location to location, averaging about $4.5 \mathrm{~m}$ thick. The second layer is soft clay and extends to about $10-15 \mathrm{~m}$ below the weathered crust. A third stiff clay layer, often fissured and about $15 \mathrm{~m}$ thick, follows the weathered crust and the soft clay. The clay layers described above, and generally called Bangkok clay, are followed by a layer of sand (the fourth layer). Below this upper sand layer (with some sandy clay), lie alternate layers of clay, and sand and gravel extends to approximately $400 \mathrm{~m}$ deep in the east and more than $1800 \mathrm{~m}$ deep west of Bangkok. Fig. 2 shows the compressibility characteristics of the clay layers at the AIT campus in Bangkok. In this figure the highly compressible characteristics of the soft clay in the upper $7 \mathrm{~m}$ are clearly evident. The medium soft clay at 11-14 m was moderately compressible, and the stiff and hard clays at deeper depths are found to be least compressible.

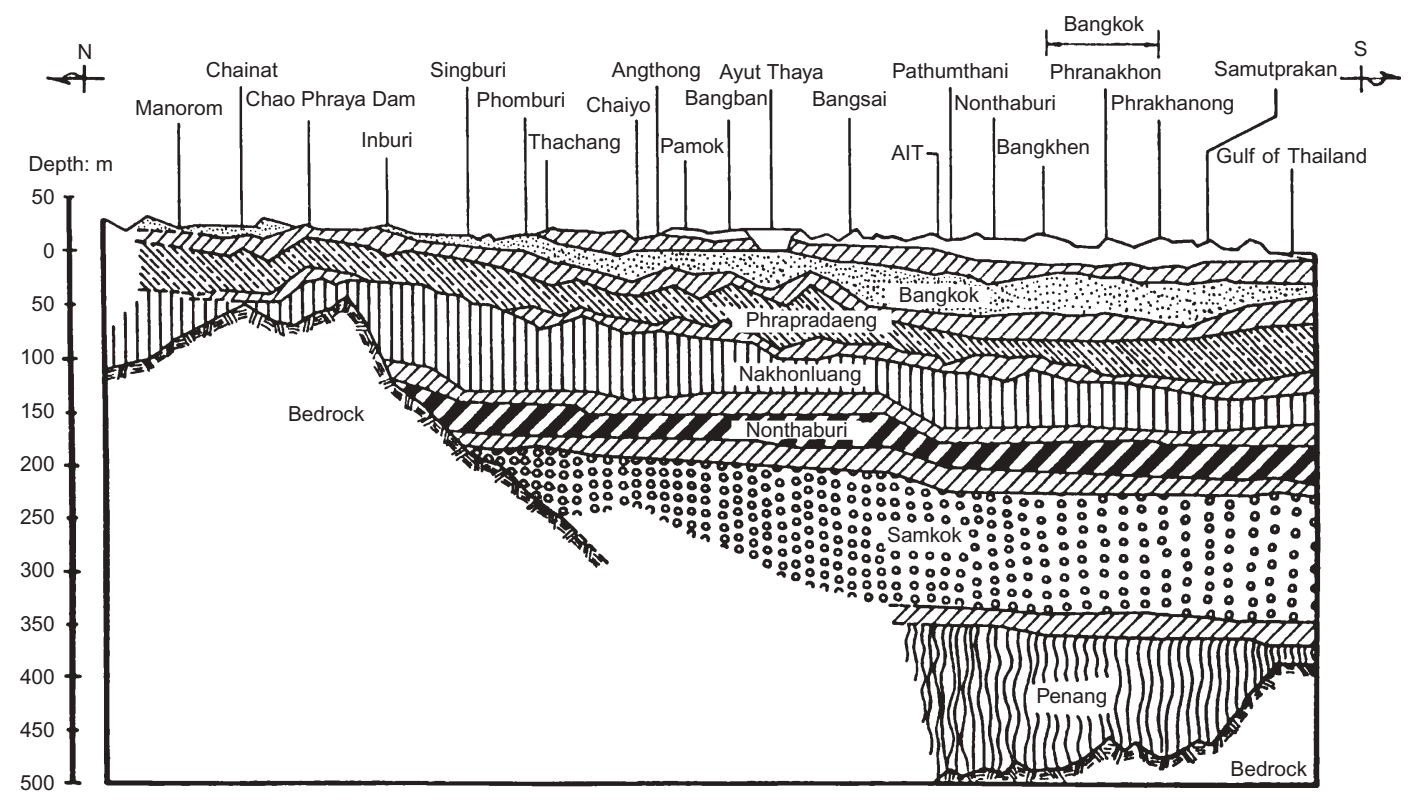

Fig. I. Hydrological profile of Bangkok aquifer system in north-south direction 


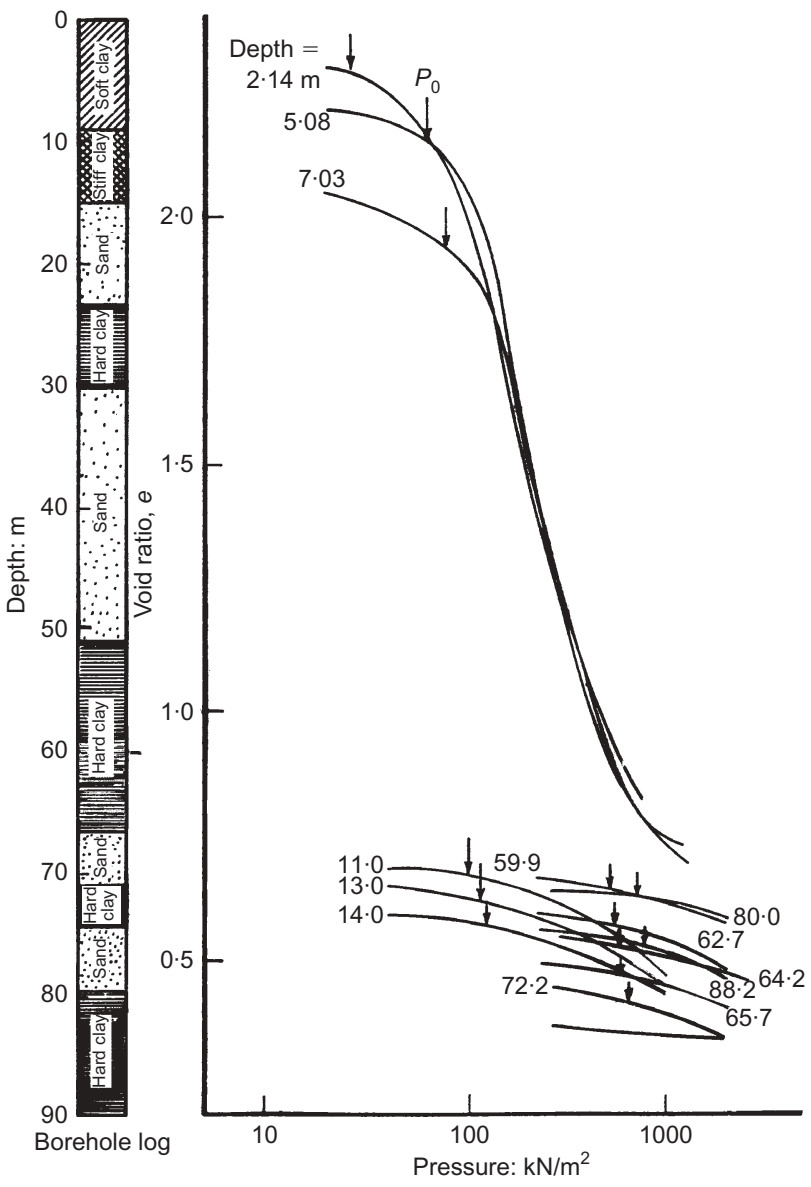

Fig. 2. Compressibility characteristics of Bangkok soft clay

According to Ramnarong and Buapeng (1991), in the upper $600 \mathrm{~m}$ there exist eight artesian aquifers, separated from each other by thick layers of clay or sandy clay. These aquifers are named Bangkok (BK), Phrapadaeng (PD), Nakornluang (NL), Nonthaburi (NB), Sam Khok (SK), Phaya Thai (PT), Thonburi (TB) and Pak Nam (PN). They are located at depths of 50, 100, 150, 200, 300, 350, 450 and $550 \mathrm{~m}$ respectively. The Bangkok aquifer is already depleted, and most of the water supply in Bangkok comes from the second (Phrapadaeng) to sixth aquifers (Phaya Thai). The seventh and eighth aquifers are used mainly for industrial water supply.

\section{Groundwater withdrawal and subsidence}

Records indicate that the deep-well pumping in 1954 was only about $8360 \mathrm{~m}^{3} /$ day, but this increased to $371000 \mathrm{~m}^{3} /$ day in 1974 and to some 1.4 million $\mathrm{m}^{3}$ in 1983. Strict groundwater control measures made this withdrawal drop between 1983 and 1987, but pumping amounts have begun rising again since 1988. As a result of this deep-well pumping and extraction of groundwater, by 1974 the water level in the Nakornluang aquifer had declined by $30 \mathrm{~m}$. This had increased to some $46 \mathrm{~m}$ by 1979 (Ramnarong, 1983). After the control measures on groundwater pumping were imposed in 1983, the piezometric level began to rise in almost all areas. The piezometric drawdown at the Second Bangkok International Airport (SBIA) Site as of 1994-1995 during the final studies related to the use of surcharge with PVD as the most suitable ground improvement technique is shown in Fig. 3. In this figure, the piezometric drawdown as measured in 1973 is also shown. In the Bangkok Plain, the piezometric drawdown has gradually increased over the years in the upper clay layer.

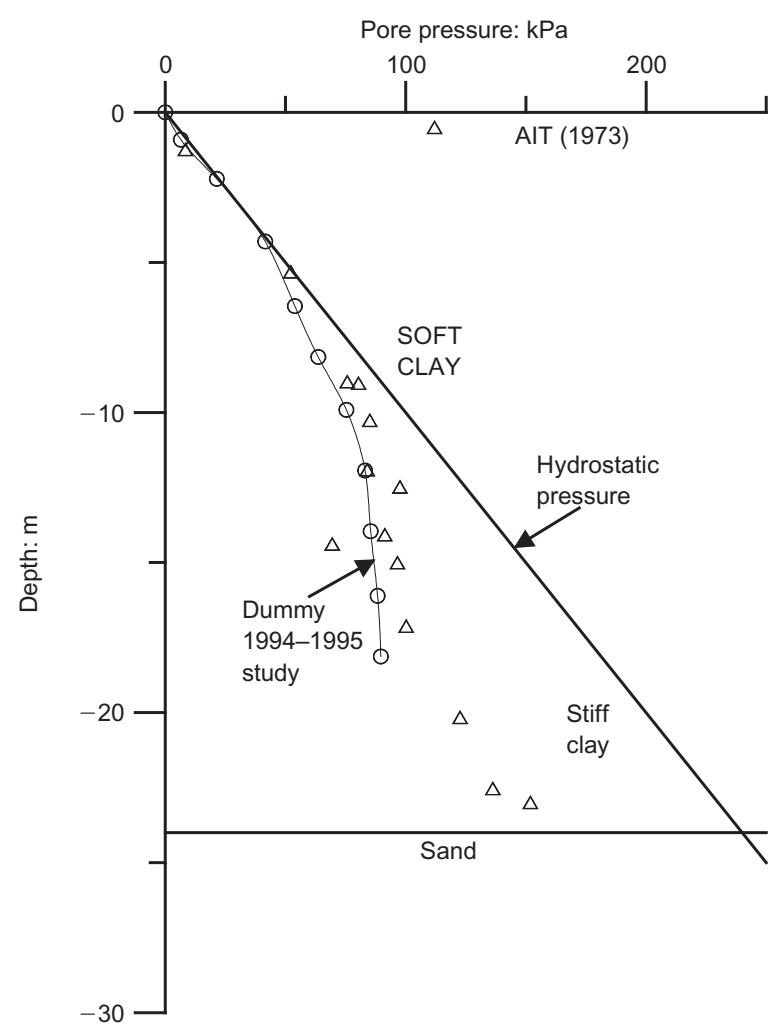

Fig. 3. Piezometric drawdown due to deep-well pumping at SBIA site

Studies related to Bangkok subsidence due to deep-well pumping started as early as 1968 (Cox, 1968; Paveenchana, 1970; Brand and Paveenchana, 1971; Brand and Balasubramaniam, 1976). However, the most comprehensive study was under the leadership of Professor Prinya Nutalaya at the Asian Institute of Technology (AIT, 1978a, 1978b, 1981; Premchitt, 1981). In these studies, the ultimate settlement was considered in three parts: due to the compression of the aquifers, the soft clay, and the stiff clay. The studies reported in AIT research reports (AIT, 1978a, 1978b) also included a mathematical model for simulation of the phenomenon of land subsidence. These pioneering works revealed that $40 \%$ of the subsidence is due to compression in the upper $50 \mathrm{~m}$ of soils, and the rest is due to the soils below. Also, at that time, the maximum subsidence was of the order of 0.05-0.10 m/year.

However, after the control measures for groundwater pumping, the subsidence rate is claimed to have reduced, and in 1988-1990 the rate was $0.03-0.05 \mathrm{~m} /$ year. It seems that the subsidence bowl shifts in the Bangkok Plain from location to location depending on the pattern of the extent of groundwater withdrawal.

\section{Test embankment with sand drains on Bangkok-Siracha Highway}

Eide (1977) reported the results of a test section on the Bangkok-Siracha Highway as measured in 1966. The ground condition along the route was considered to be very soft. Sand drains of $0.2 \mathrm{~m}$ diameter were installed by the displacement method. They were placed in a triangular pattern at $2 \mathrm{~m}$ spacing. The observed settlement during a two-year period after the construction is shown in Fig. 4. Sand drains increased the rate of settlement, but not to a sufficient degree. The most negative aspect quoted by Eide (1977) was that, even though the sand drain accelerated the 


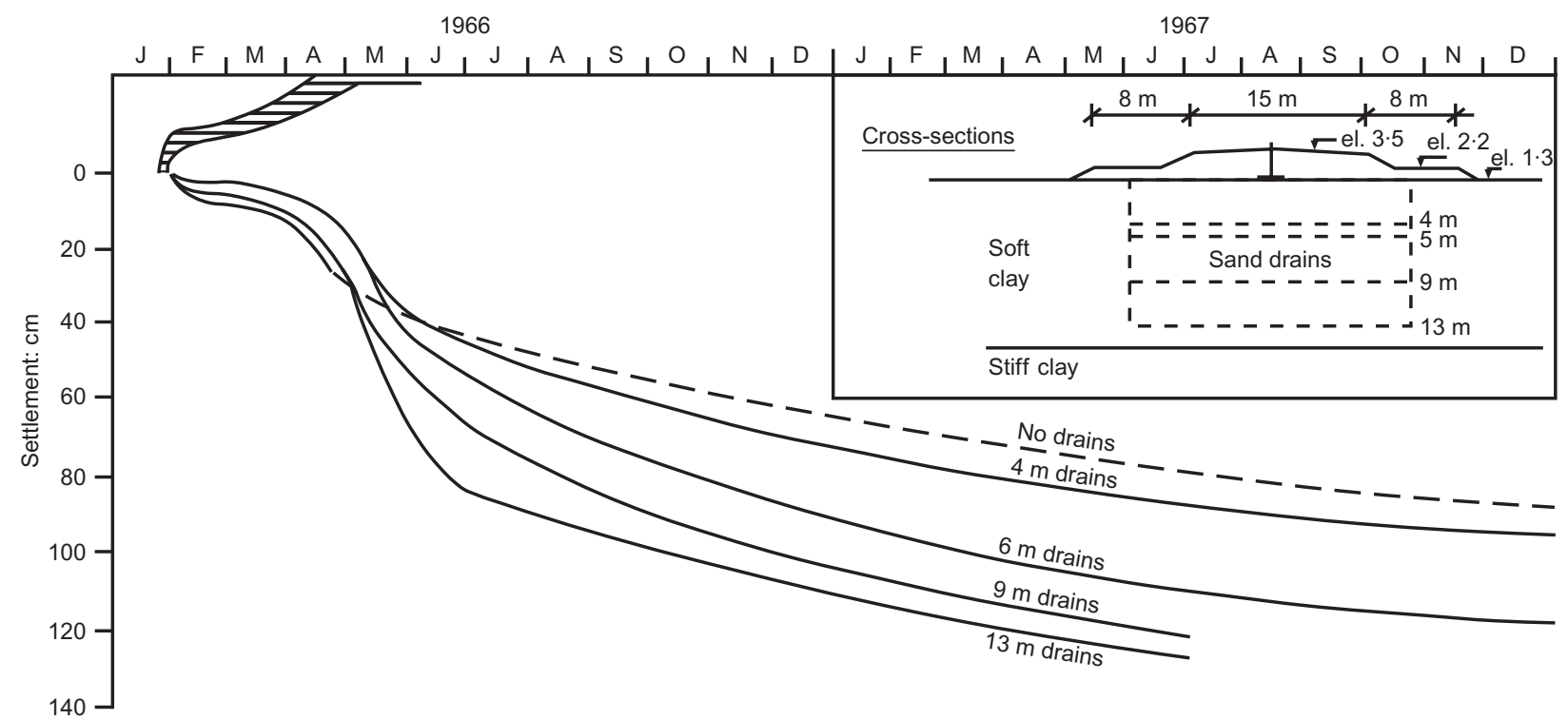

Fig. 4. Observed settlements on test section with sand drains at Bangkok-Siracha Highway (after Eide, 1977)

consolidation in the first 18 months, at the end of this period the rate of settlement was still as much as $0.03 \mathrm{~m} / \mathrm{month}$, which was considered to be high. Possibly because of the low factor of safety, a substantial part of the total settlement was due to continuous undrained creep without volumetric strain, when the stress states were close to failure.

\section{Test embankment with sand wicks at the Royal Thai Navy (RTN) dockyard, Pom Prachul, Thailand}

\section{Test embankment and soil profile}

The performance of sand drains (sand wick type) at the Naval Dockyard site, Pom Prachul, was investigated in 1975 by constructing an instrumented test embankment. The test site is situated at the mouth of the Chao Phraya River in Samut Prakarn province, approximately $20 \mathrm{~km}$ south of Bangkok city. The embankment, which was built in two stages, was $90 \mathrm{~m}$ long, $33 \mathrm{~m}$ wide, $2 \cdot 35 \mathrm{~m}$ high, and consisted of three sections: a section with no drains, a section with $2.5 \mathrm{~m}$ spacing, and a section with drains at $1.5 \mathrm{~m}$ spacing (as shown in Figs 5(a) and $5(\mathrm{~b}))$. The sand drains consisted of small diameter $(0.05 \mathrm{~m})$, sand wicks and were installed to a depth of $17 \mathrm{~m}$ by the displacement method. These sand wicks were constructed at the site by pouring sand inside a permeable membrane. First a closed-end steel casing, $75 \mathrm{~mm}$ internal diameter, was driven into the ground; the sand wick was lowered into the casing, which was then withdrawn. A total of 166 piezometers were installed below the test fill area and outside it. Surface and subsurface settlement points were installed to monitor the settlement along the centreline and the edges of the test embankment. Three hydrostatic profile gauges were installed, one along each central cross-section of a test section. Also, 11 magnetic movement plates were used to monitor lateral displacements along the gauge. Three inclinometer casings were installed along the centreline of each test section. The typical soil profile at the site is shown in Fig. 5(c).

\section{Pore pressure measurements below the test embankment}

The loading pattern for the three test sections and the pore pressure observations are shown in Fig. 6(a). Before con- structing the test embankment a sand blanket of $0.35 \mathrm{~m}$ was placed, and this corresponded to a surcharge pressure of $5.5 \mathrm{kN} / \mathrm{m}^{2}$. Then the first stage of loading was carried out in 25 days with a fill height of $1.1 \mathrm{~m}$ and a surcharge pressure of $19 \mathrm{kN} / \mathrm{m}^{2}$. Thus at the end of the first stage of loading the surcharge pressure was $24.5 \mathrm{kN} / \mathrm{m}^{2}$. After a waiting period of 60 days, the embankment was raised to $2.35 \mathrm{~m}$ (inclusive of the $0.35 \mathrm{~m}$ sand blanket). The second-stage loading was for a period of 1 month, and the observations were continued for a total period of 10 months.

Piezometers P41, P27 and P13 located at 7.5 m depth in the three sections indicated a consistent rise during the loading phase and a drop in values during the waiting period and under the time observed after the full surcharge. These piezometers measured the absolute values of the pore pressures, and thus included the original groundwater pressure before loading. As shown in Fig. 6(a), the static groundwater pressure was observed from the observation well with hydrostatic assumptions and no drawdown. The dummy piezometers installed at a location far away from the test embankment and without the influence of the sand wick and the surcharge gave the static water pressure inclusive of any possible drawdown due to deep-well pumping. At this site the piezometric drawdown starts only at a depth below $7.5 \mathrm{~m}$, and so the hydrostatic water pressures indicated by the observation well and the dummy piezometers located at $7.5 \mathrm{~m}$ depth are more or less coincident, indicating very small drawdown. Fig. 6(b) illustrates the piezometric drawdown profile at this site.

All 166 piezometers were indicating consistent values of pore pressure. However, the active piezometers installed at depths of 10-15 $\mathrm{m}$ indicated that the piezometric drawdown below the embankment is more or less erased by the sand drain, which has recharged the drawdown area back to its hydrostatic conditions. Thus at deeper depths the absolute values of the piezometer readings under the embankments will be a sum of the static water pressure without any drawdown and the excess pore pressure induced by the surcharge loading. In order to clarify the situation, additional piezometers were installed along the centreline of the longitudinal section of the test embankment from the northern edge corresponding to the closely spaced sand drain section and also along the edge of the eastern boundary of the test embankment (as shown in Figs 7a and $7 \mathrm{~b}$ ). These figures indicate that at the edge of the embankment, both in the north direction along the longitudinal centreline and in the east direction along the centreline of the 


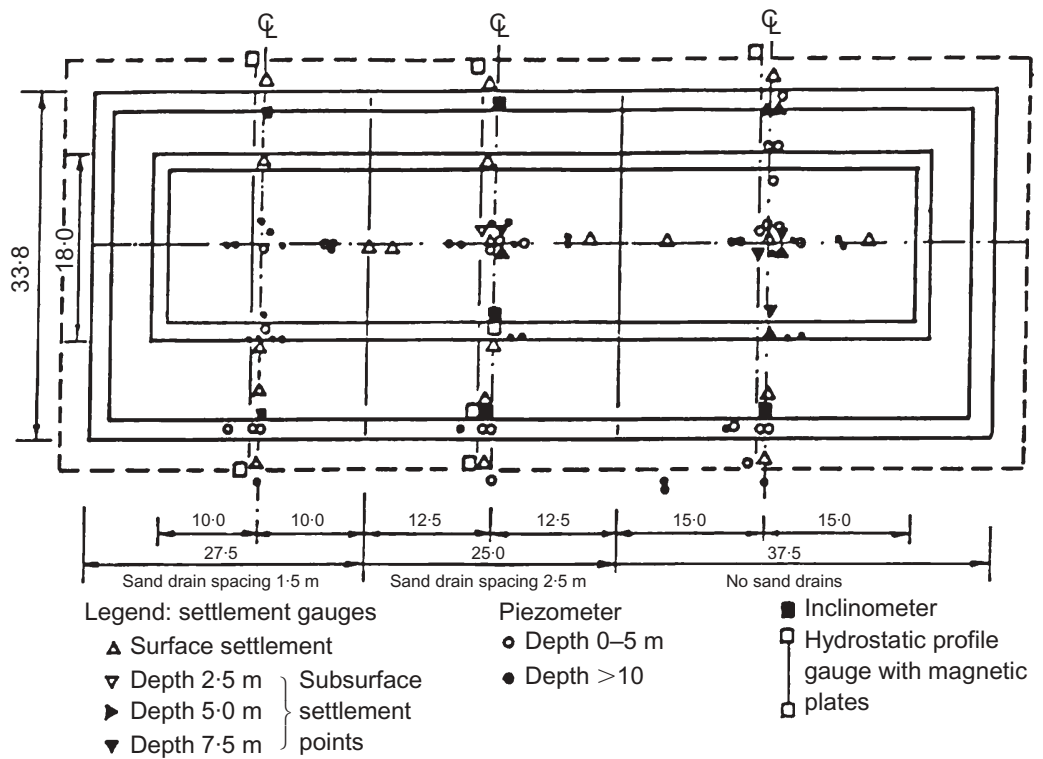

(a)

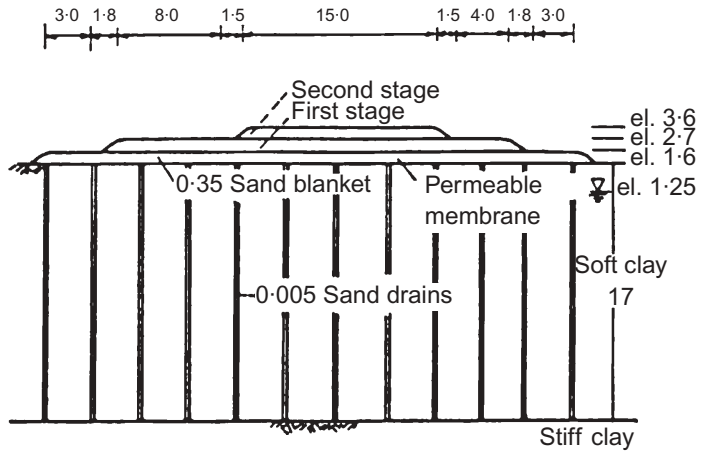

(b)

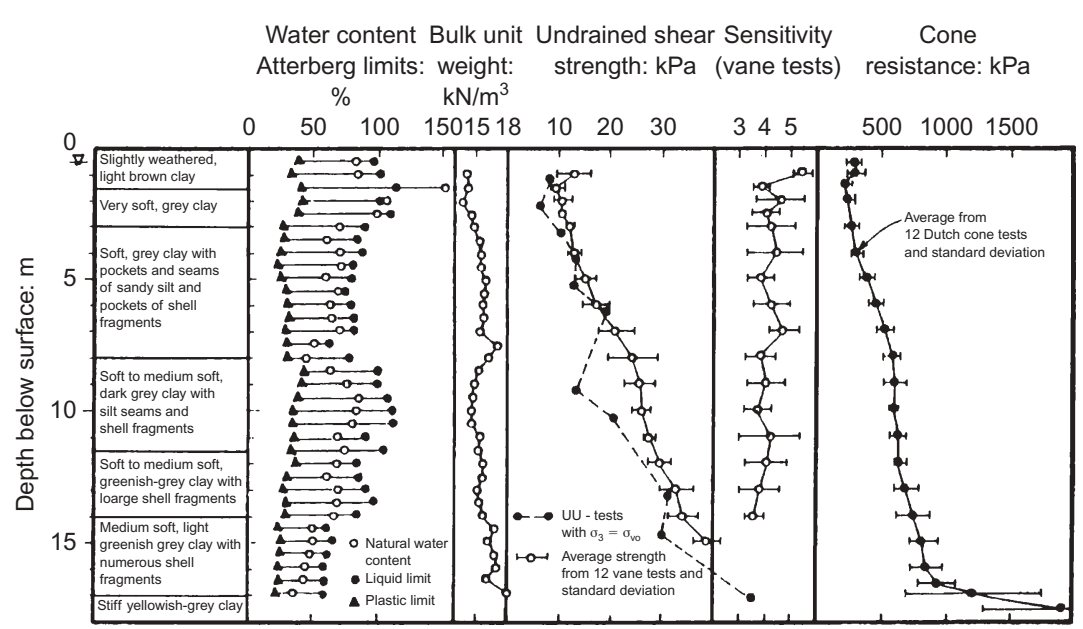

(c)

Fig. 5. RTN Dockyard site: (a) plan of test embankment; (b) elevation of test embankment (all dimensions in metres); (c) general properties of Pom Prachul clay

north-south direction, there was no drawdown at $14 \mathrm{~m}$ depths. In both directions the full drawdown was realised only at distances of about 15-20 $\mathrm{m}$ away from the edges of the embankment. This would indicate that having the three sections side by side without any space in between them was a grave mistake in planning the overall testing programme. Ideally speaking, the three sections should be separated from each other, with substantial allowance for the zone of influence of the drains in recharging the drawdown area below the embankment. This was observed in the final planning of the test embankment with PVDs at the Second Bangkok International Airport (SBIA) site in the 1994-1995 studies. The three test embankments at the SBIA site were separated from each other, with substantial space between them.

\section{Measured and computed settlements at dockyard site}

Settlement records from 47 active settlement plates have been studied, and typical cases are plotted in Fig. 8. In this 


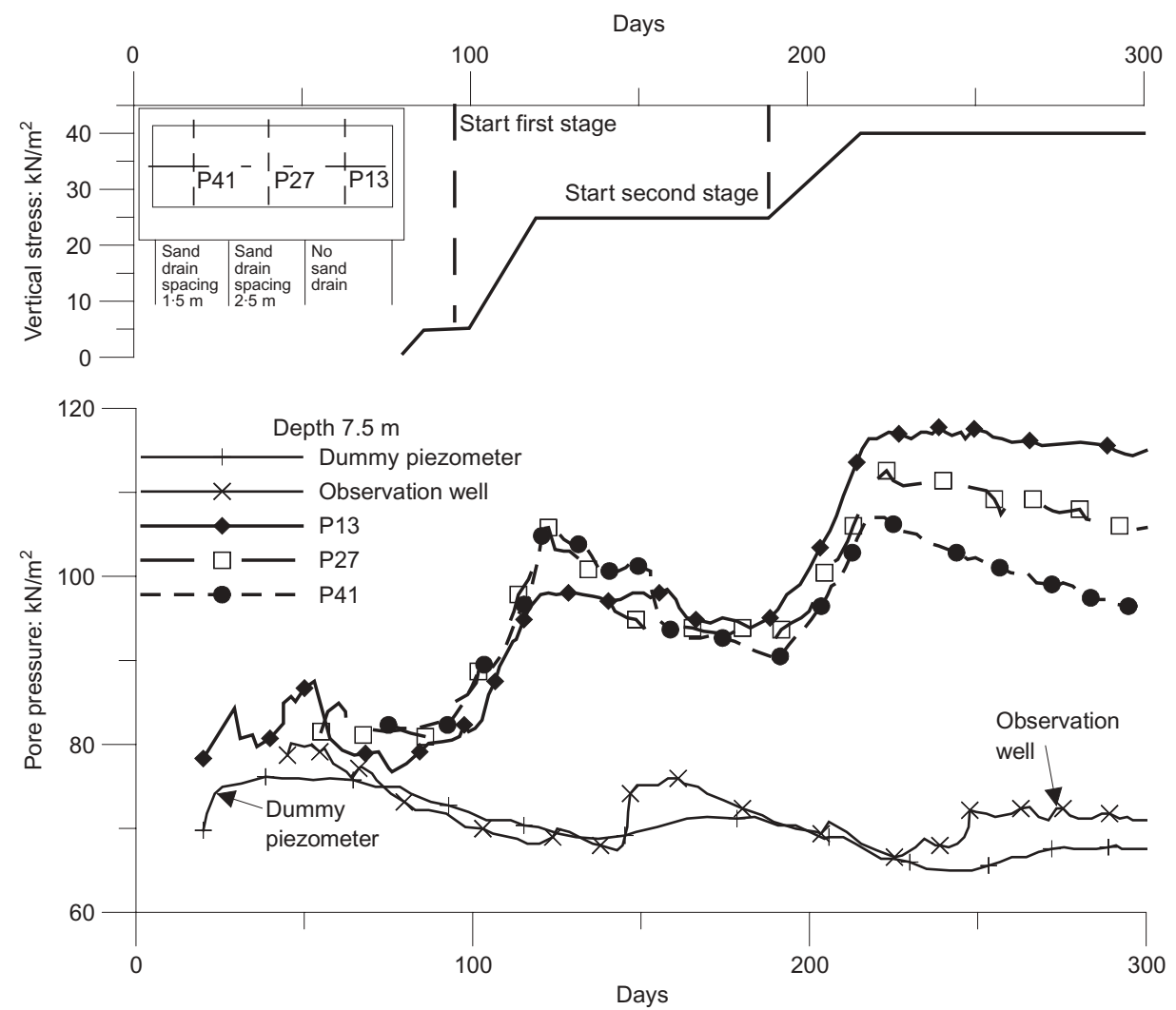

(a)

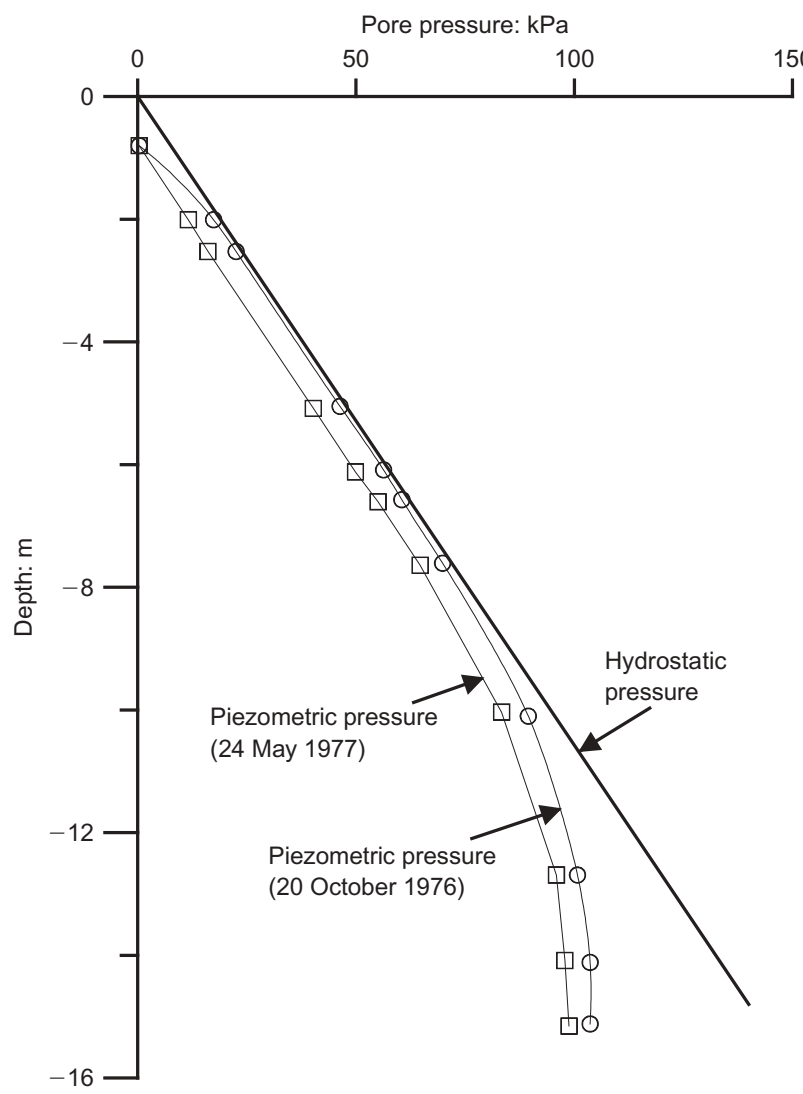

(b)

Fig. 6. RTN Dockyard site: (a) typical piezometer readings; (b) variation of piezometric pressures with depth

figure the surface settlement at the centreline of the three test sections is plotted with respect to time. Also shown in this figure is the loading pattern with time in terms of the surcharge stress (vertical stress increment). These settlement records are in accordance with the pore pressure dissipation, shown in Fig. 6(a). The section with closer drain spacing showed higher settlements than the one with wider spacing and the one with no drain. It has already been discussed that the wider-spaced drain section was interfering with the nodrain section. Thus substantial lateral drainage would have 


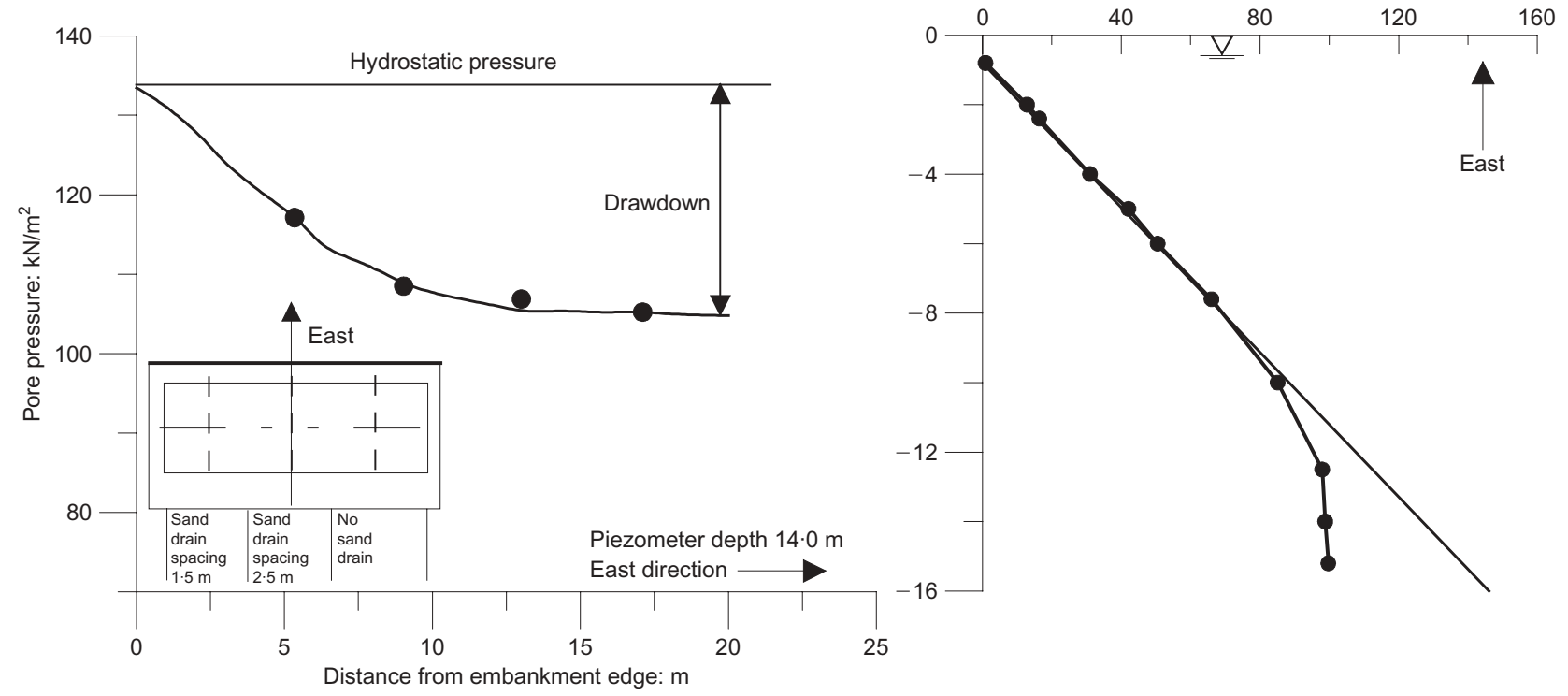

(a)

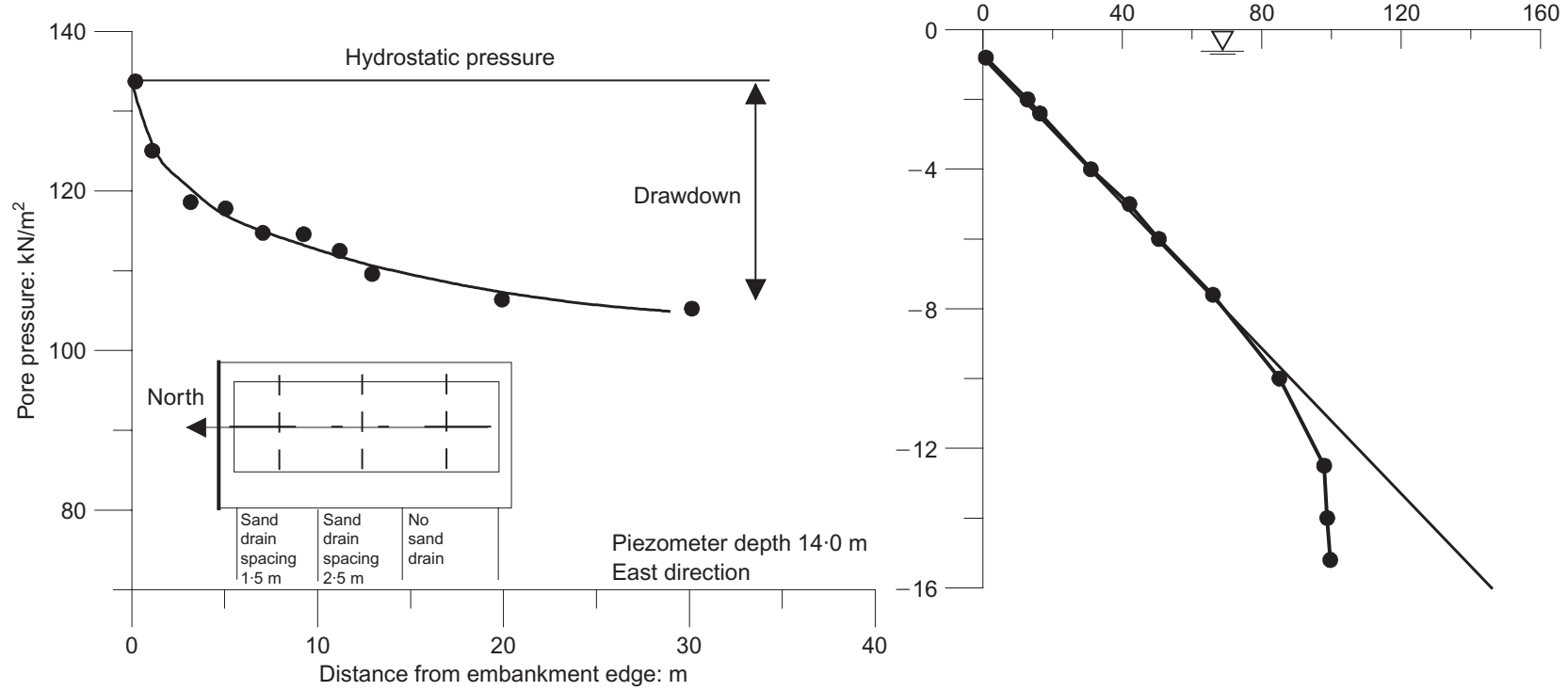

(b)

Fig. 7. Piezometric pressure against distance from edge of embankment at RTN Dockyard site: (a) east direction; (b) north direction

taken place in the no-drain section, owing to the influence of the nearby adjoining drain section with wider spacing.

Using the elastic theory for increment in stresses below the test sections and the undrained modulus from $C K_{0} U$ triaxial tests, immediate settlements were computed, and are plotted in Fig. 9. It can be seen that very little immediate settlement occurs below a depth of $11 \mathrm{~m}$. The immediate surface settlements under the first-stage loading and the second-stage loading were computed to be $36 \mathrm{~mm}$ and $115 \mathrm{~mm}$ respectively. The total primary consolidation settlement under the embankment loading was calculated using the stress-strain curves from oedometer tests. Fig. 10 shows the variation of the primary consolidation settlement with depth. In Fig. 10 the consolidation settlements were computed from six series of consolidation tests performed with the Lever Arm Consolidometer, Anteus Consolidometer and Bishop Consolidometer. In series SC seven tests were conducted from 1 to $16 \mathrm{~m}$ with $24 \mathrm{~h}$ load increment duration and load increment ratio of one. A similar series of tests was conducted in the Anteus Consolidometer as Test Series AC.
The Bishop Consolidometer was used in test series BC, and the load increment duration and ratio were similar to series SC and AC. In test series SI, small load increments were used in the Lever Arm Consolidometer to determine the accurate determination of the preconsolidation pressure. The measured settlements were in the drained section with $1.5 \mathrm{~m}$ drain spacing. These data indicate that, even in the $1.5 \mathrm{~m}$ drained section, the primary consolidation was not yet completed.

From the observed settlement reading, the compression of each $2.5 \mathrm{~m}$ layer within the no sand drain area and the two sand drain areas was calculated and plotted against time. This is shown in Fig. 11, and it can be seen that, for the top $5.0 \mathrm{~m}$, the rate of settlement is faster for the $1.5 \mathrm{~m}$ spaced sand drain area. However, below $5.0 \mathrm{~m}$ depth, no significant improvement is noted with the use of sand drains.

The time rate of settlement was calculated according to one-dimensional consolidation theory. The settlement of $2.5 \mathrm{~m}$ thick layers corresponding to the location of settlement measuring points was considered. The maximum drainage 


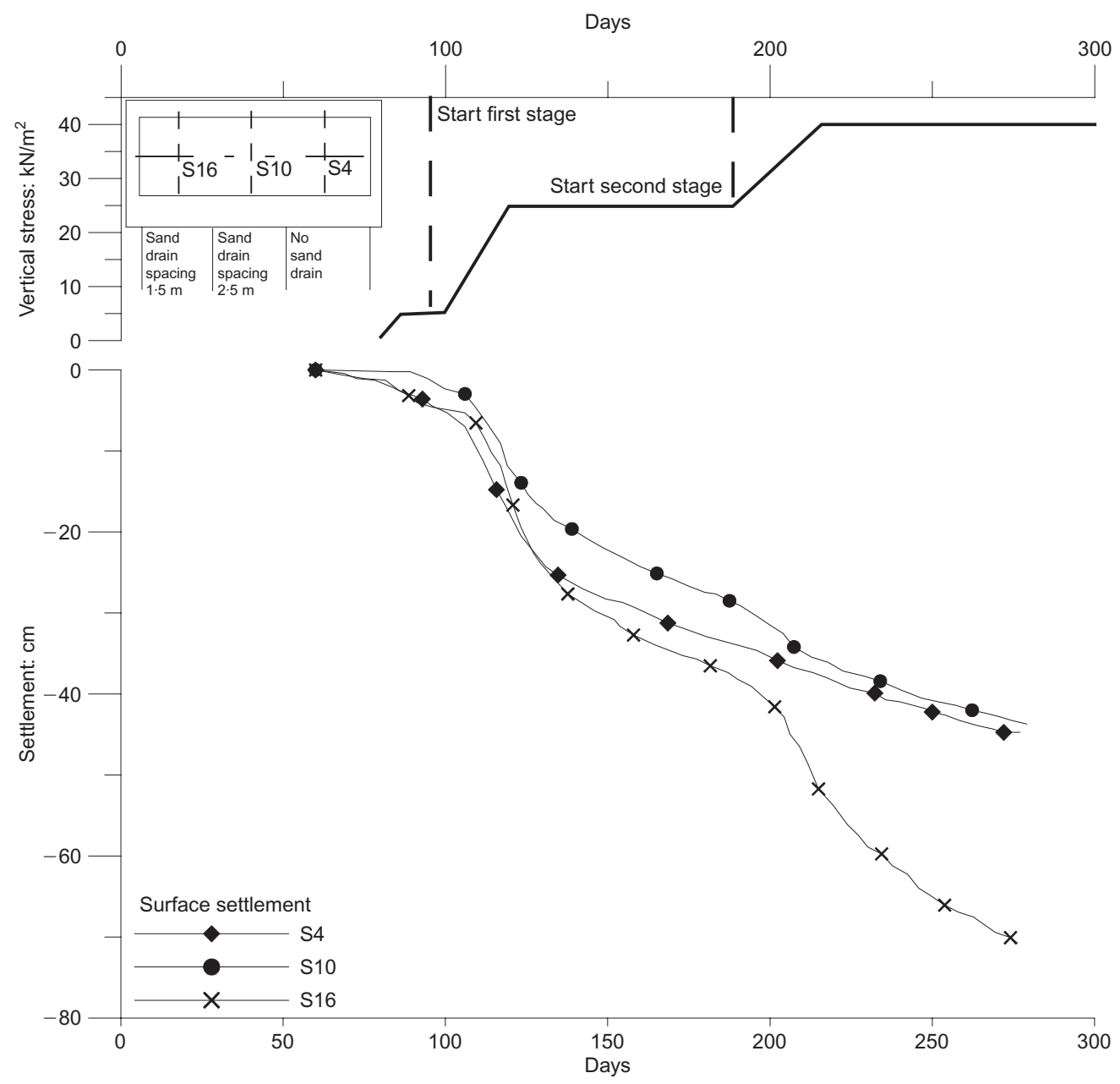

Fig. 8. Typical settlement point readings at RTN Dockyard site

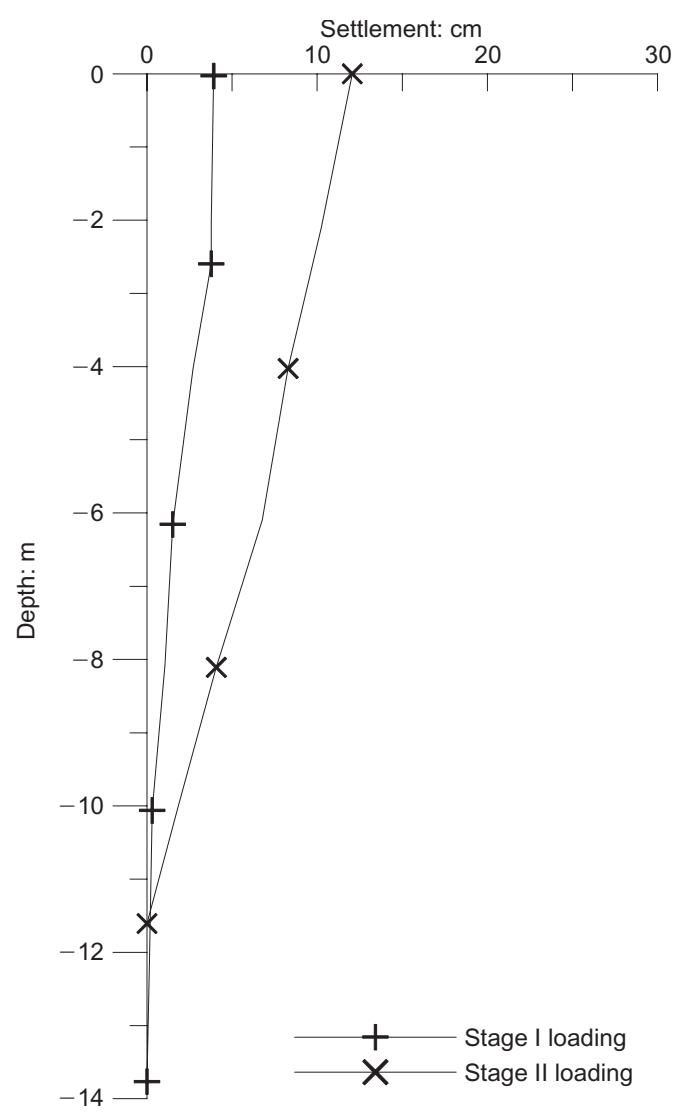

Fig. 9. Immediate settlement below embankment at RTN Dockyard site path was taken as the effective radius of the sand drain installation pattern. The sand drain installation follows a rectangular pattern, and the effective diameters for the $1.5 \mathrm{~m}$ spaced and $2.5 \mathrm{~m}$ spaced areas are $1.7 \mathrm{~m}$ and $2.83 \mathrm{~m}$ respectively. The solutions derived by Schiffman $(1958,1960)$ were used in calculating the degrees of consolidation. As a first approximation, it was assumed that these solutions were applicable, although the directions of settlement and drainage were not the same.

Figure 12 shows a plot of settlement against time for the $2.5 \mathrm{~m}$ thick layers of soil in the $1.5 \mathrm{~m}$ spaced drain area. Also plotted in the diagram are the settlements calculated as explained above for different assumed values of $c_{\mathrm{V}}$. The immediate settlement as calculated before has been added. From the figures, it can be seen that for the top $2.5 \mathrm{~m}$ layer of soil the observed settlements were very much greater than those calculated during the first stage of loading. The greater rate of settlement in the field may be due to the presence of root holes (or fissures, etc.) near the surface, which form shorter drainage paths to accelerate the consolidation process. However, after the second stage of loading, the settlement curve, obtained using a $c_{\mathrm{V}}$ value of $20 \times$ $10^{-4} \mathrm{~cm}^{2} / \mathrm{s}$, was close to the observed value. Fig. 13 shows the results for the $2.5 \mathrm{~m}$ spaced sand drain area. For the layer between 2.5 and $5 \mathrm{~m}$ the computed settlement curve, with a $c_{\mathrm{V}}$ value of $20 \times 10^{-4} \mathrm{~cm}^{2} / \mathrm{s}$, agreed fairly well with the observed curve. For the layer between 5 and $7.5 \mathrm{~m}$, a $c_{\mathrm{V}}$ value of $5 \times 10^{-4} \mathrm{~cm}^{2} / \mathrm{s}$ gave good agreement with the measured settlements during the first stage of loading. However, after the second-stage loading, the measured values were very much greater than the predicted ones. 


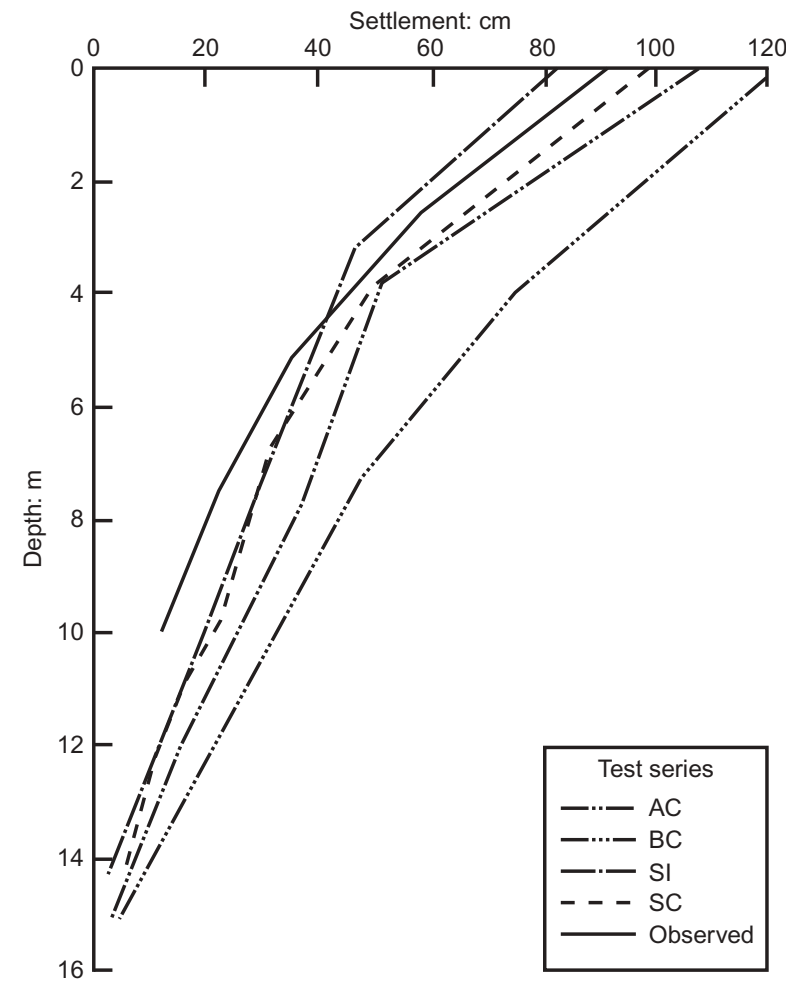

Fig. 10. Consolidation settlement below embankment as calculated at RTN Dockyard site

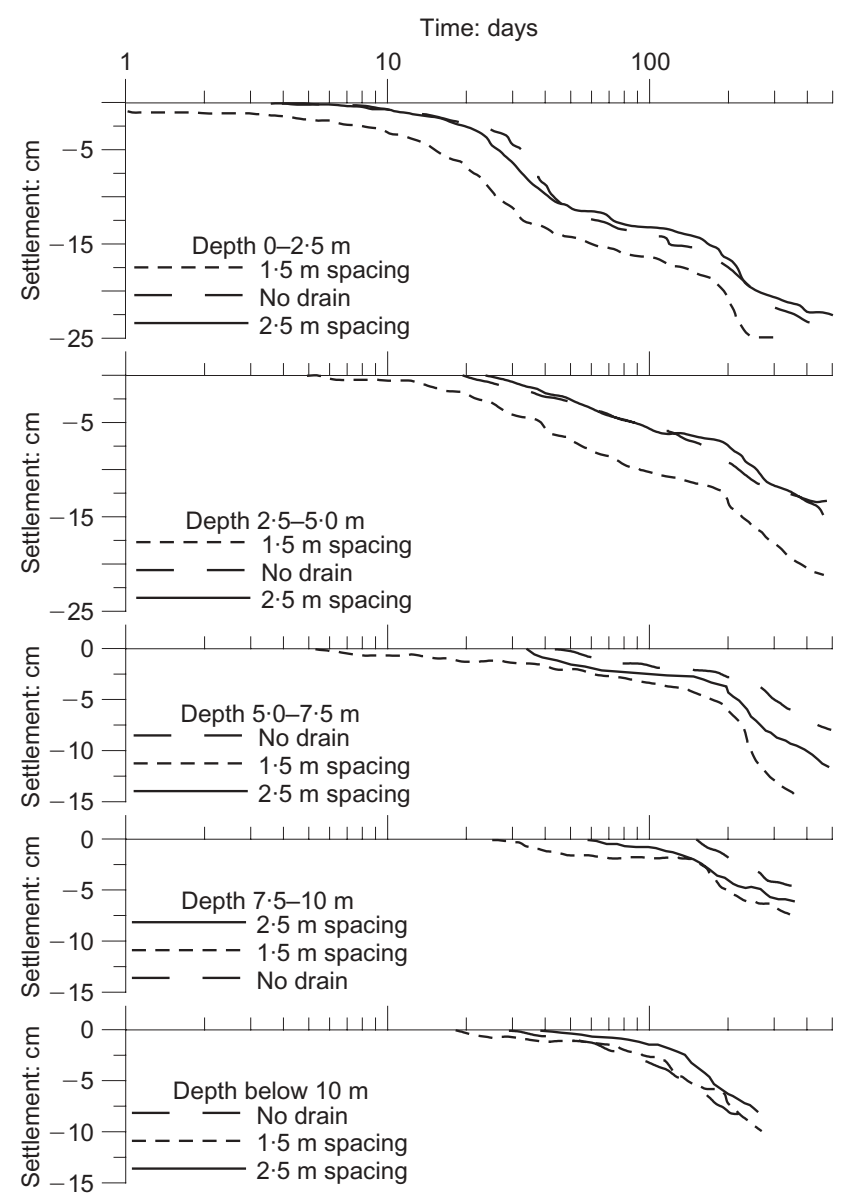

Fig. II. Comparison of settlement-time records in sections with and without drains at RTN Dockyard site

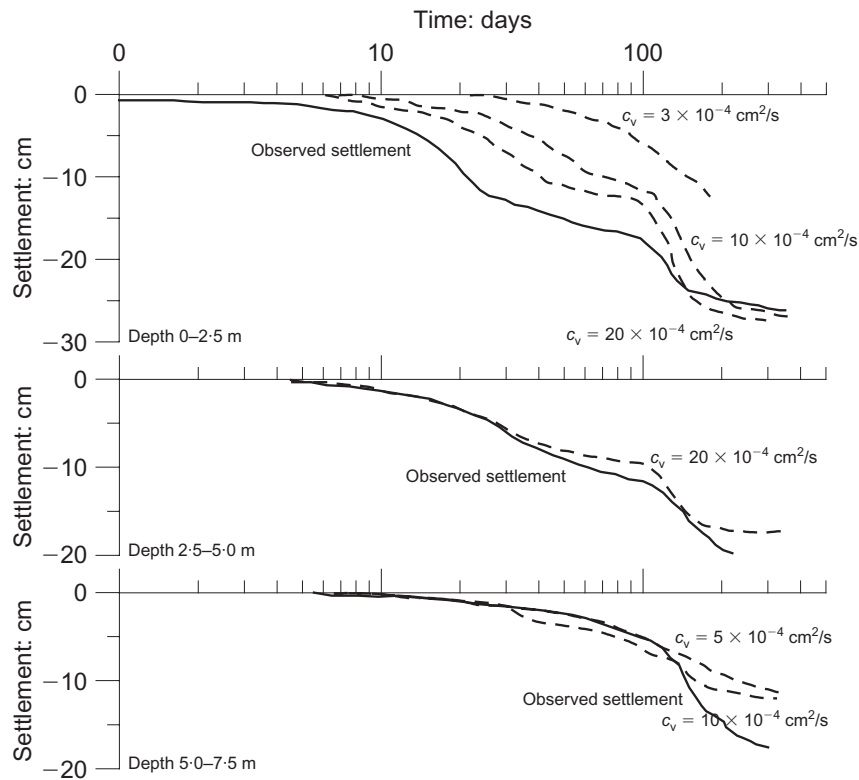

Fig. 12. Observed and calculated settlements ( $1.5 \mathrm{~m}$-spaced sand drains sections) at RTN Dockyard site

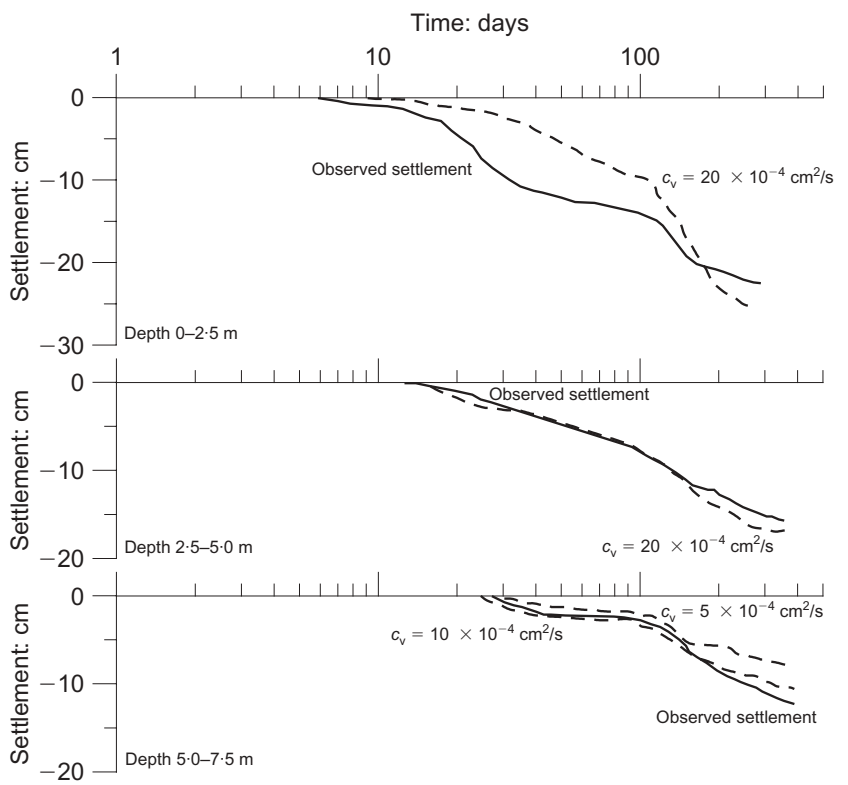

Fig. 13. Observed and calculated settlements $(2.5 \mathrm{~m}$-spaced sand drains sections) at RTN Dockyard site

The major lesson learnt from this trial embankment was that the sand wick drains had recharged the zone that was originally under piezometric drawdown. Thus for the bottom layer of the soft clay the recharging would have resulted in a decrease in the effective stress, and this is the reason why the settlements were smaller below the upper $5 \mathrm{~m}$, where there was no drawdown before. Also, the recharging zone seems to extend laterally up to a distance of about $15 \mathrm{~m}$, and so the no-drain section would have been influenced by the drained section. It would therefore have been better to have had three separate sections spaced out in such a manner that there was minimum interference, and the data from each embankment truly represented a no-drain section and the sections with the wider and narrower spacing of drains. 


\section{Test embankments at the SBIA site}

At the SBIA site in Nong Ngu Hao, the most extensive sand drain studies on test embankments were performed in 1983 (Moh and Woo, 1987) as part of the ground improvement scheme for the runway pavement and other sections of the taxiways and landside roads. Sand drains of minimum diameter $0.26 \mathrm{~m}$ were installed to a depth of $14.5 \mathrm{~m}$ by water jetting. The test programme included three test areas: one with surcharge fill, a second with vacuum loading, and a third with groundwater lowering. Test section 1 was $40 \mathrm{~m} \times$ $40 \mathrm{~m}$ in plan, and sand drains were installed at $2 \mathrm{~m}$ spacing in a triangular pattern. The vacuum load was not successful, as several leaks developed, and finally the section was covered with a plastic shield. Test section 3 was similar to Test section 1, except that the spacing of the drains was increased to $2.4 \mathrm{~m}$. Because of similar problems as in section 1 , the loading was not successful. Test section 2 was slightly larger than test section 1 , and preloading of $60 \mathrm{kN} / \mathrm{m}^{2}$ was applied in three stages. Although difficulties were encountered in maintaining the vacuum load as well as the groundwater lowering, the embankment surcharge was found to be a reliable technique when compared with vacuum loading in accelerating the consolidation with sand drains. The settlement observations are presented in Figs 14 and 15 as taken from Moh and Woo (1987). The field trial was not successful in the sense that: (a) there was a settlement of $0.4 \mathrm{~m}$ under a sand blanket of $0.7 \mathrm{~m}$ after a five-month period, and (b) the settlement across the section was remarkably asymmetric. The observations indicate the possibility of hydraulic connections between the sand drains and the first sand layer located at $25 \mathrm{~m}$ depths with a piezometric drawdown of $120 \mathrm{kN} / \mathrm{m}^{2}$. It appears that sand wicks (as used at the Naval Dockyard site) recharged the piezometric drawdown in the clay layer, while the large-diameter sand drains (like those used in the airport site in 1983) tended to form hydraulic connections with the underlying aquifer and caused additional settlements due to the piezometric drawdown.

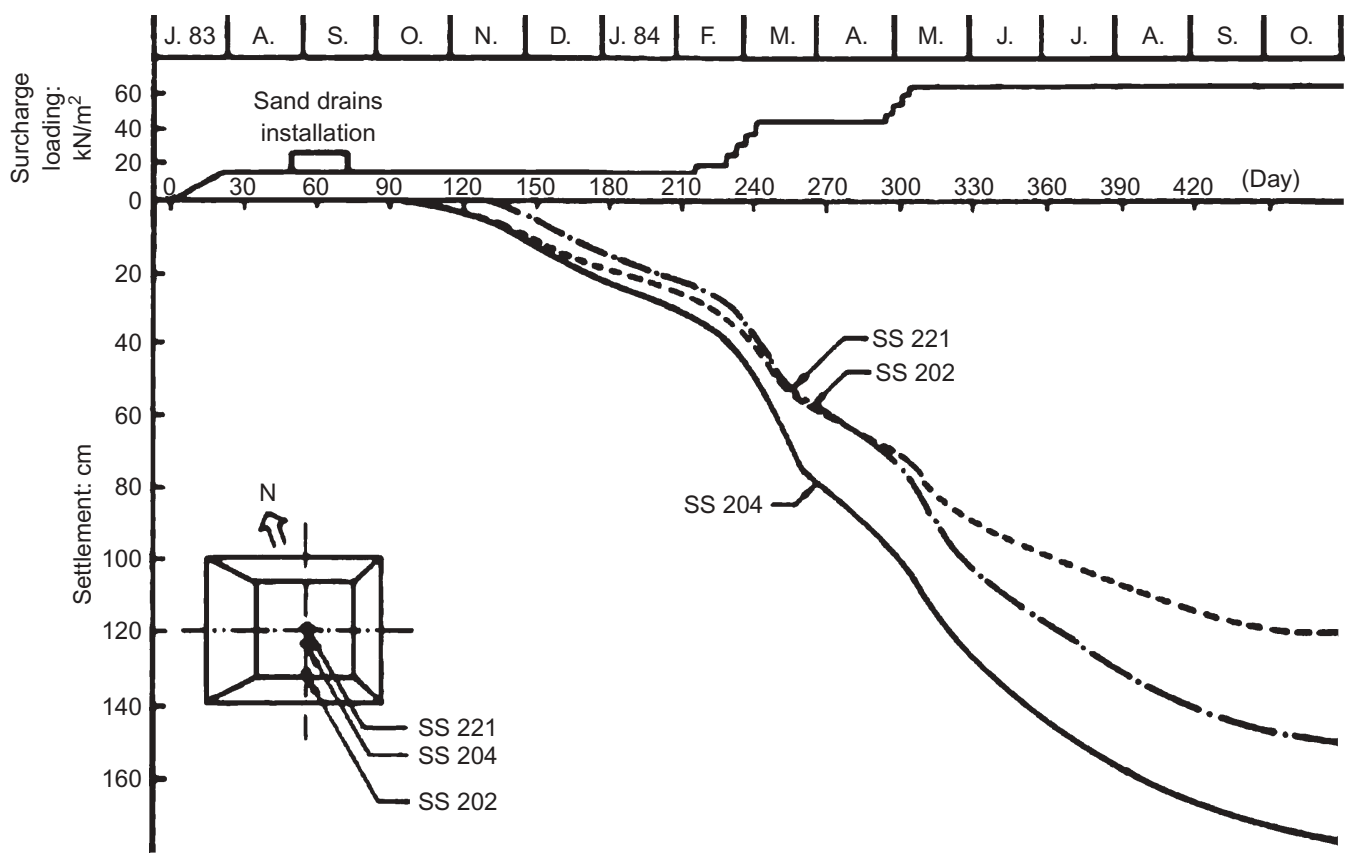

Fig. 14. Observed settlements for test embankment with sand drains at SBIA (Moh and Woo, 1987)

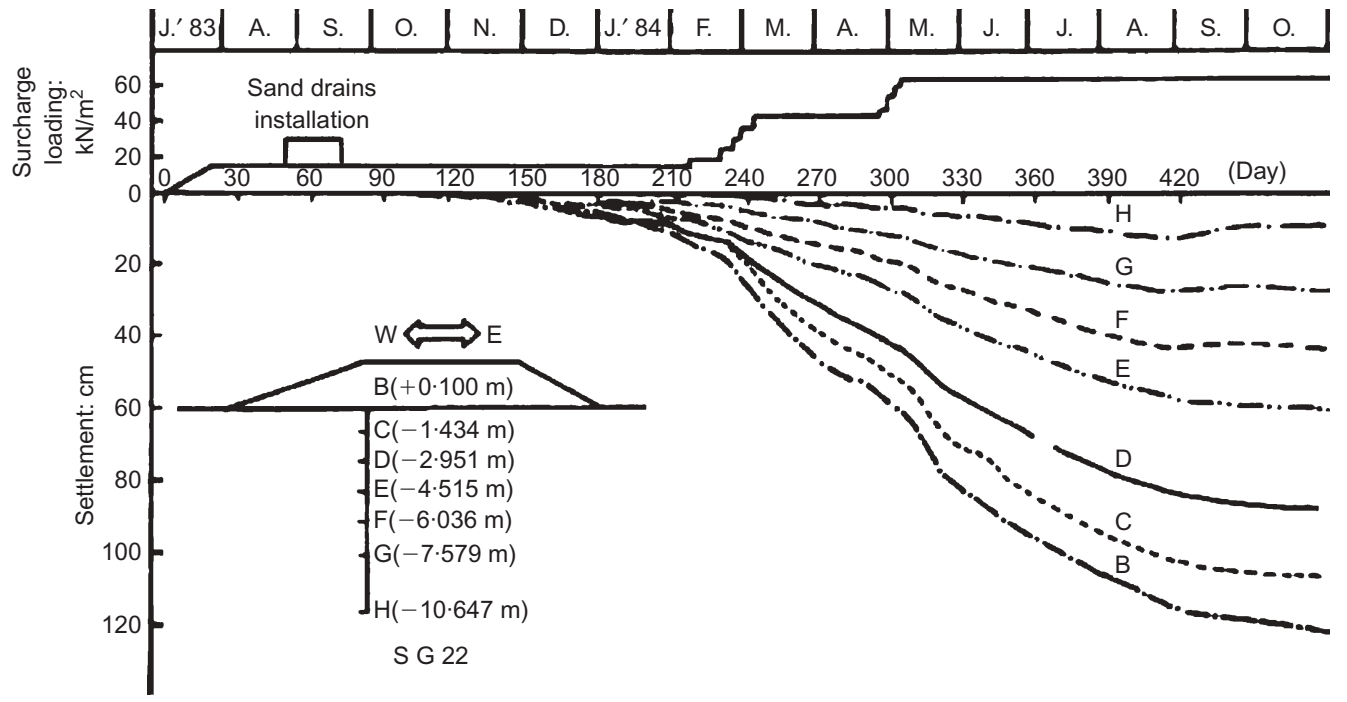

Fig. 15. Vertical settlements of soil layers for test embankment with sand drains at SBIA (Moh and Woo, 1987) 


\section{Test embankment with PVDs at the SBIA site}

From the previous trials, it become evident that the engineers in Bangkok were rather cautious of the potential use of vertical drains in the Bangkok Plain, and the clientthat is, the Airport Authority of Thailand-insisted that the 1994-1995 study must indicate beyond all doubt that most of the settlement experienced in the trial embankment was of the consolidation type, to indicate the removal of water from the soft clay to improve its strength characteristics as well as to ensure that there were no possible hydraulic connections between the PVDs used and the underlying sand stratum, which was experiencing substantial piezometric drawdown. These objectives were to be met by estimation of the degree of consolidation, both from direct measurement of the settlements and from observation of the pore pressure dissipation in the field. Further, in-situ tests were conducted with a vane apparatus to measure the insitu strength increase with the water content reduction from the consolidation due to the use of PVDs and surcharge. Additionally, the rate of settlement with time needed to be plotted to indicate that the final settlement rate was comparable to that which one would consider acceptable at a rate similar to those experienced in secondary consolidation, and not of higher values corresponding to hydraulic connections.

The plan dimensions of the embankments were the same as in the earlier study. The locations of the test embankments and the cross-section of embankment TS3 with PVDs are shown in Figs 16 and 17 respectively. These embankments were fully instrumented to measure the surface and subsurface settlements and pore pressures, lateral movements and heave. PVDs were installed to $12 \mathrm{~m}$ depth, and

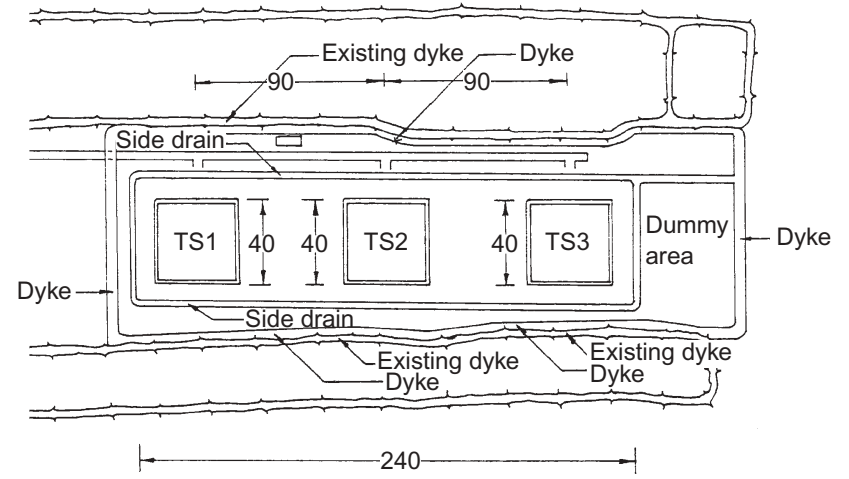

Fig. 16. Site plan of test embankments TSI, TS2 and TS3 at SBIA site the spacing was $1.5,1.2$ and $1.0 \mathrm{~m}$ in the three embankments TS1, TS2 and TS3 respectively.

\section{Settlement and pore pressure plots}

All three test embankments performed more or less in the same manner, and therefore detailed discussion will be based on only one (test embankment TS3 with PVD spacing at $1 \mathrm{~m}$ intervals). For this embankment the settlement profile with depth and the pore pressure plots at various times are shown in Figs 18 and 19. Fig. 18 shows the settlement profiles at the end of construction (270 days), after 450 days (June 1995) and after 660 days (February 1996).

Settlements were also independently computed from actual pore pressure dissipation. In Fig. 19, the dotted curve $\mathrm{ABC}$ represents the actual piezometric profile with drawdown as observed in September 1994, prior to the construction of the embankment. The full curve DEF corresponds to the pore pressure profile after the full height of the embankment was reached with a surcharge of $75 \mathrm{kPa}$, but prior to any pore water pressure dissipation. The pore pressure profile at the end of construction is also shown. Similarly the pore pressure profiles in June 1995 and in February 1996 are also shown. The final pore pressure after the dissipation of the excess pore pressure and the recharged hydrostatic profile is MNPQ (NPQ is the assumed final recharged pore pressure profile, where there are no data points). Settlements were directly computed from these pore pressure dissipation curves.

The degrees of consolidation computed from the pore pressure dissipations are illustrated in Fig. 20. Fig. 21 compares the degree of consolidation as computed from settlement measurements with those estimated from the pore pressure dissipation. In Fig. 21 , the ordinate axis $U_{\mathrm{p}}$ refers to the degree of consolidation as computed from the pore pressure dissipation, and the abscissa axis refers to the degree of consolidation $U_{\mathrm{s}}$, as computed from the settlement measurements. With due allowance for a small percentage of secondary settlement and creep, the two degrees of consolidation seem to agree well, as they are close to the $45^{\circ}$ line. Because of limitations in the length of the paper, the data related to the lateral movements are not presented here. The settlement due to the lateral movements was less than $10 \%$ as estimated by the method of Loganathan et al. (1993). The rate of settlement and the rate of lateral movement are plotted in Figs 22 and 23, and are seen to decay with time. Also, the plots of settlement log time plots in Fig. 24 for the test embankments were found to be approaching a constant

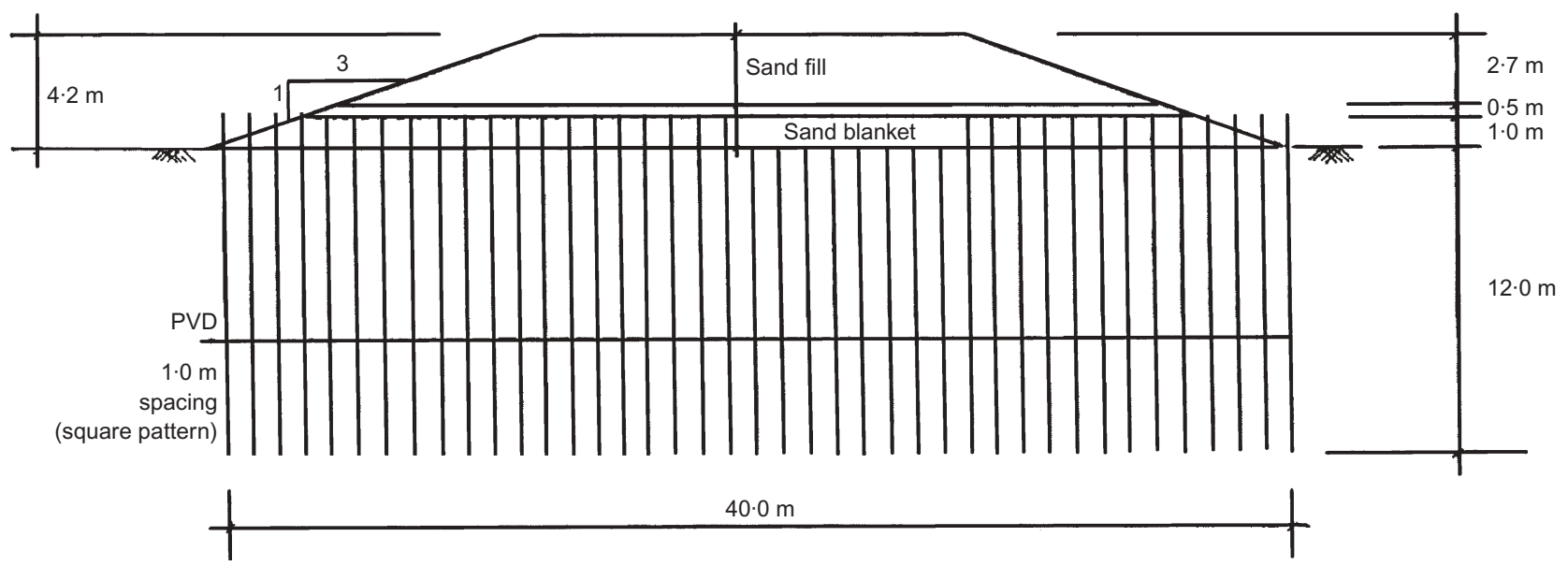

Fig. 17. Test section TS3 showing PVDs at SBIA site 


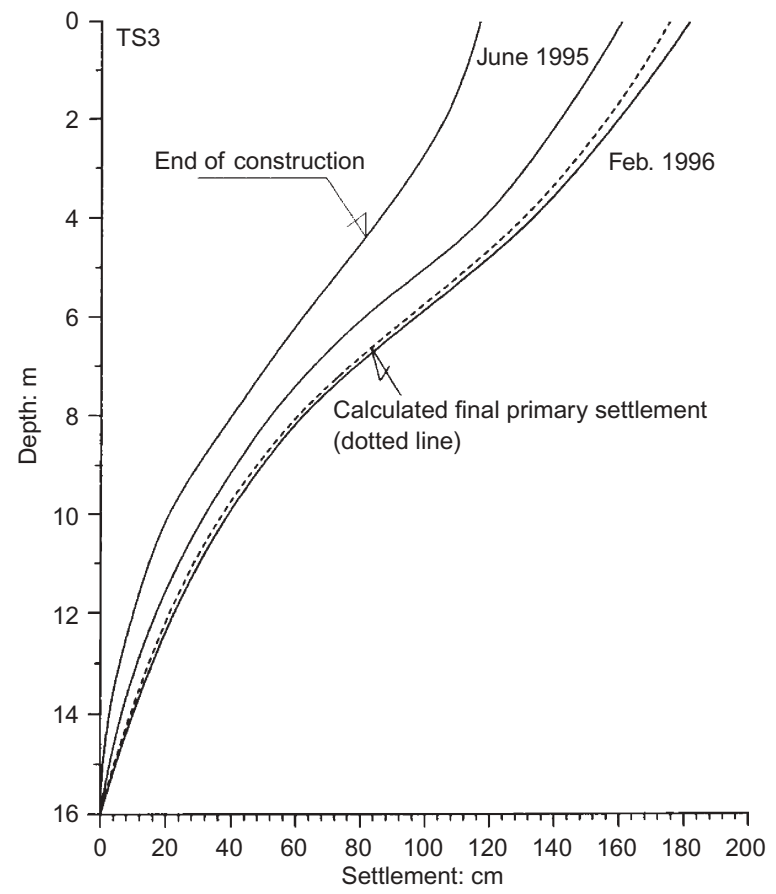

Fig. 18. Settlement plot of test embankment with PVD at SBIA site

slope. An attempt was made to define the $100 \%$ primary consolidation time using plots of Casagrande-type settlement against $\log$ time. The points $\mathrm{P}$ and $\mathrm{Q}$ in Fig. 24 correspond to the $100 \%$ primary consolidation for test sections TS3 and TS1 respectively. The data for TS2 are not

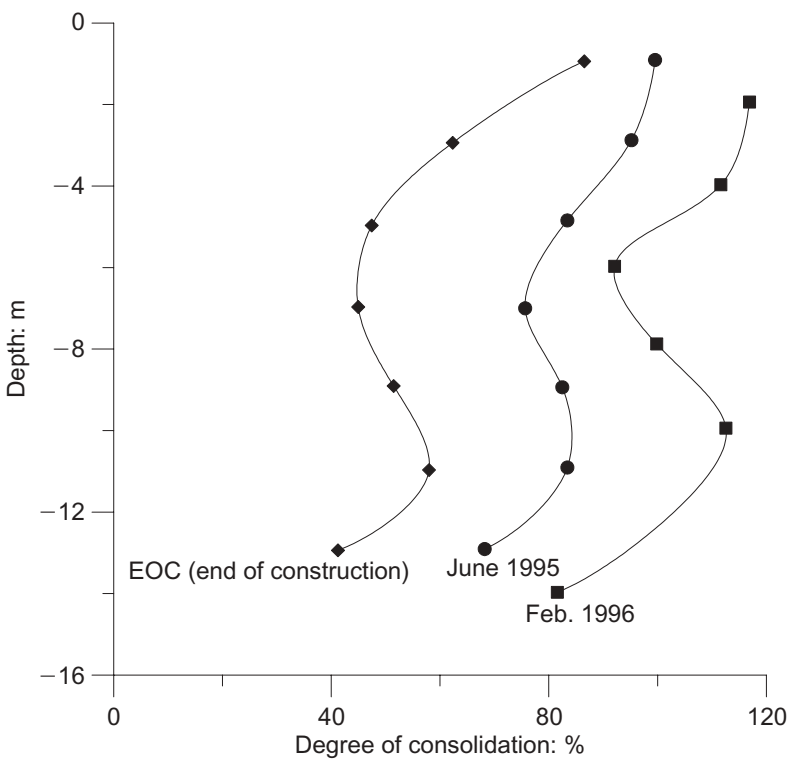

Fig. 20. Degree of consolidation from measured pore pressure at SBIA site

shown, as they would crowd closely with the data from the other two embankments. The final portions of the test data for the two embankments seem to approach the secondary consolidation part as computed from the plots of Casagrande settlement against log time. These results further confirm that the PVDs did not cause any hydraulic connection with the lower aquifers, and the measured final settlement is of the same order as the secondary settlement.

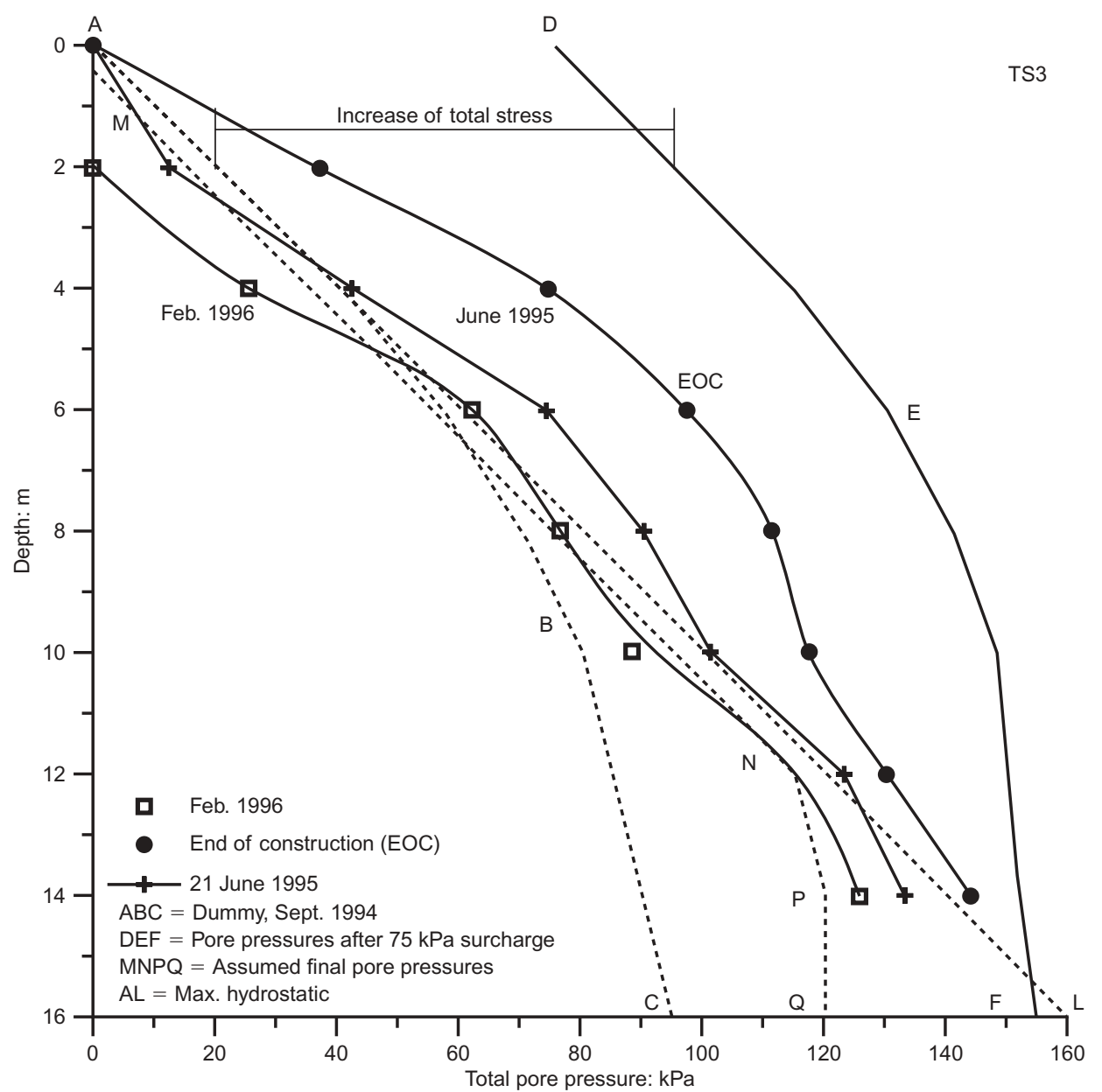

Fig. 19. Pore pressure profile of test embankment with PVD at SBIA site 


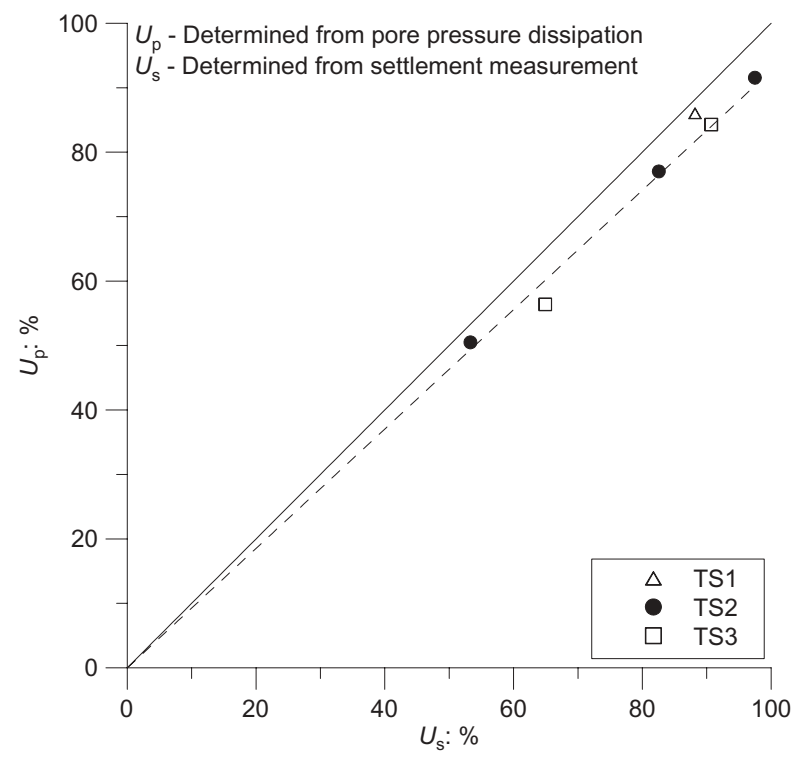

Fig. 21. Degree of consolidation computed from pore pressure dissipation and settlement measurements at SBIA site

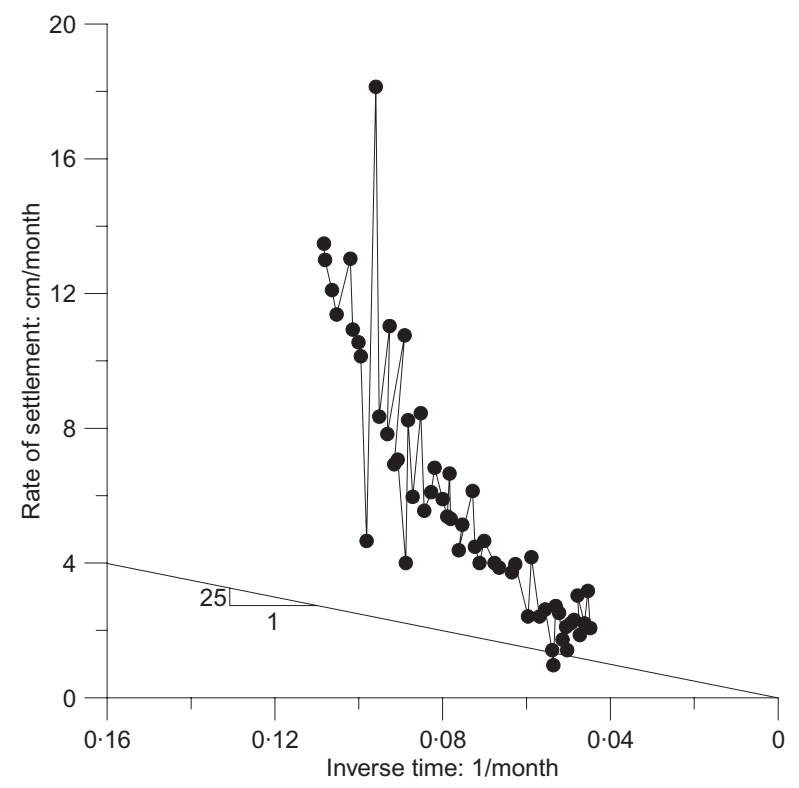

Fig. 22. Rate of settlement against inverse time plot at SBIA site

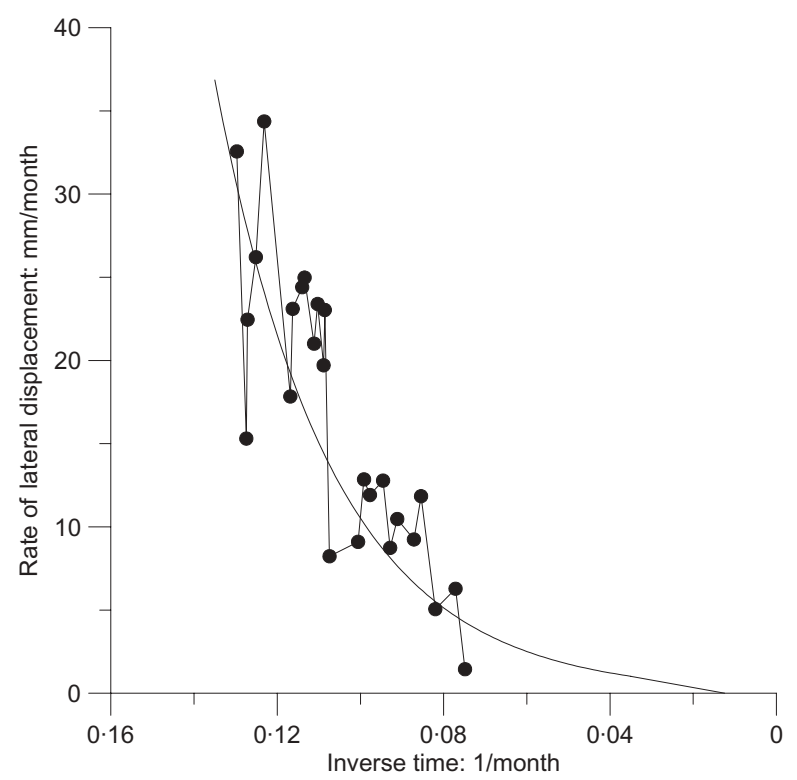

Fig. 23. Rate of lateral movement against inverse time plot at SBIA site

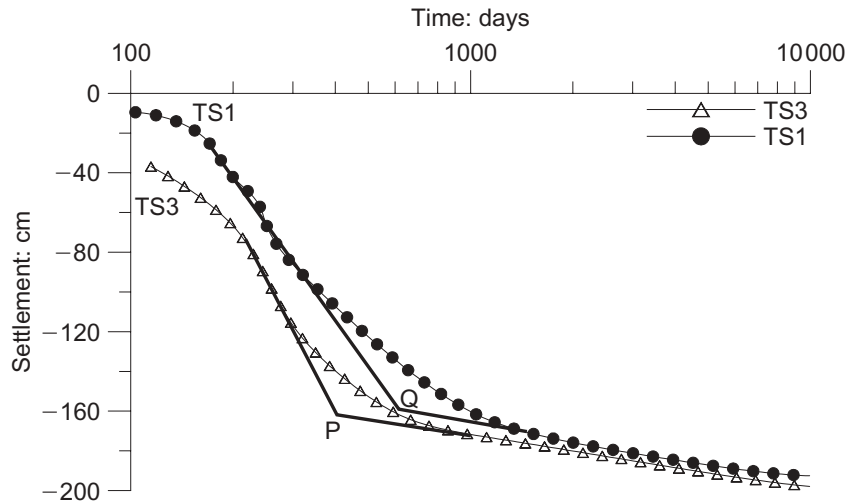

Fig. 24. Settlements against log-time plot for embankments TSI and TS3 at SBIA site

Finally, the increase in shear strength with time after consolidation in the field was measured with the vane apparatus, and is plotted in Fig. 25.

\section{Conclusions}

Full-scale test embankments were constructed at three sites in the Bangkok Plain to explore the feasibility of using surcharge with vertical drains as a means of ground improvement in the underlying soft clay. The aquifer system

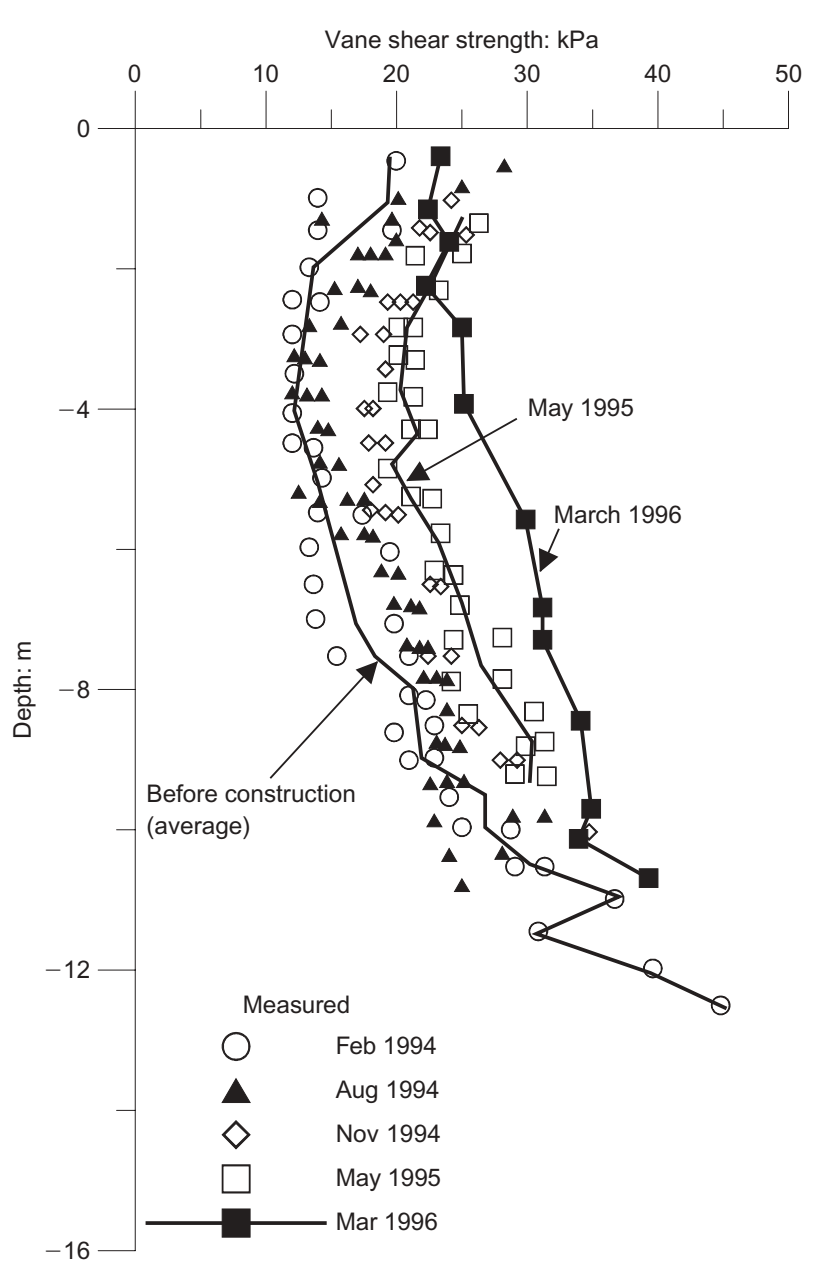

Fig. 25. Field vane shear strength as measured in embankment TS3 at SBIA site 
below the Bangkok Plain is undoubtedly very complex (eight interconnected and leaky aquifers are identified, ranging in depth from $20 \mathrm{~m}$ to $530 \mathrm{~m}$ ) and the thickness of the sedimentary deposit varies from $550 \mathrm{~m}$ to $2000 \mathrm{~m}$. Extensive deep-well pumping has caused very large piezometric drawdown, and there is continuous surface subsidence. From the data gathered, the following conclusions can be reached:

(a) The test embankment studied by Eide (1977) was on very soft clay: the use of $0.2 \mathrm{~m}$ sand drains would have disturbed the underlying very soft clay, and substantial undrained creep would have influenced the settlement rate. Also, no indication was given as to the effect of subsidence due to groundwater withdrawal.

(b) The study in 1975-1977, related to the test embankment at the Royal Thai Navy Dockyard in Pom Prachul, Bangkok, had three distinct sections, one with closer sand wick spacing of $1.5 \mathrm{~m}$, one with wider spacing of $2.5 \mathrm{~m}$, and one with no drains. Pore pressure measurements below the test embankment and in its neighbourhood indicated that the sand wicks had recharged the zone of piezometric drawdown below a depth of $7.5 \mathrm{~m}$, and also had a recharging influence to a distance of 15$20 \mathrm{~m}$ from the edges of the drained section. This resulted in the no drains section having a substantial degree of drainage. Also, the surcharge used in the test embankment was not sufficiently higher than the preconsolidation pressure of the soft clay at this site.

(c) The 1983 test embankments at the SBIA site indicated that the method of vacuum drainage was not successful, because of several leaks, and because of the difficulty of maintaining the vacuum pressure continuously for a long time. Also, the test embankment with vertical drains indicated possible hydraulic connections with the underlying sand aquifer.

(d) The 1994-1995 studies conducted at the SBIA site on test embankments with surcharge and PVDs were found to be most successful as the ground improvement technique to strengthen the engineering properties of the soft clay with the removal of water by consolidation settlement. The settlements computed from pore pressure dissipation agreed with those computed from the direct settlement measurements, as well as the strength increase observed with time as the consolidation of the soft clay progressed with time. The lateral movements (though not discussed here) were found to contribute less than $10 \%$ of the total vertical settlement. The rates of settlement decay and lateral movement decay were also analysed to confirm that the primary consolidation phase had indeed completed during the preloading period.

\section{Acknowledgements}

The work presented in this paper relates to the research work conducted by the first author over a period of 27 years at the Asian Institute of Technology as sponsored research projects and graduate thesis research work. The close collaboration that the first author enjoyed, with several discussions with the late Ove Eide of the Norwegian Geotechnical Institute, and with former colleagues Dr Za-Chieh Moh, Dr E. W. Brand and Professor Prinya Nutalya, is gratefully acknowledged. The Royal Thai Navy and the Airport
Authority of Thailand are thanked for engaging the first author and his team in carrying out the elaborate full-scale field tests and the interpretation of the data presented in this paper. The first author is also most grateful to the large number of Masters students and research associates at AIT, who helped him in carrying out the work presented in this paper for a 27-year period.

\section{References}

AIT (1978a) Investigation of Land Subsidence Caused by Deep-well pumping in Bangkok Area. Asian Institute of Technology, Bangkok, GTE Internal Research Report (Phase I Progress Report).

AIT (1978b) Investigation of Land Subsidence Caused by Deep-well pumping in Bangkok Area. Asian Institute of Technology, Bangkok, GTE Internal Research Report (Phase I Final Report).

AIT (1981) Investigation of Land Subsidence Caused by Deep-well pumping in the Bangkok Area. Asian Institute of Technology, Bangkok, Internal Research Report.

Brand E. E. and Paveenachana T. (1971) Deep-well pumping and subsidence in the Bangkok area. Proceedings of the 4th Asian Regional Conference on Soil Mechanics and Foundation Engineering, Bangkok, 1, 1-7.

Brand E. W. and Balasubramaniam A. S. (1976) Soil compressibility and land subsidence in Bangkok. Proceedings of the International Symposium on Land Subsidence, Anaheim, CA, pp. $365-374$.

Cox J. B. (1968) A Review of the Engineering Characteristics of the Recent Marine Clays in Southeast Asia. Asian Institute of Technology, Bangkok, Thailand, Research Report No. 6.

EIDE O. (1968) Geotechnical Engineering Problems with Soft Bangkok Clay on the Nakhon Sawan Highway Project. Norwegian Geotechnical Institute, Oslo, Publication No. 78.

EIDE O. (1977) Exploration, sampling and insitu testing of soft clay in the Bangkok area. Proceedings of the International Symposium on Soft Clay, Bangkok, pp. 122-137.

Loganathan N., Balasubramanaim A. S. and Bergado D. T. (1993) Deformation analysis of embankments. Journal of Geotechnical Engineering, ASCE, 119, No. 8, 1185-1206.

Moн Z. C. and Woo S. M. (1987) Preconsolidation of Bangkok clay by non-displacement sand drains and surcharge. Proceedings of the 9th Southeast Asian Geotechnical Conference, Bangkok, 1, 287-296.

Moh Z. C., Nelson J. D. and Brand E. W. (1969) Strength and deformation behaviour of Bangkok clay, Proceedings of the 7 th International Conference on Soil Mechanics and Foundation Engineering, Mexico City, 1, 287-295.

Muktabhant C., Teerawong P. and Tengamnuay V. (1967) Engineering properties of Bangkok subsoils. Proceedings of the Southeast Asian Conference on Soil Engineering, Bangkok, 1, 1-7.

Paveenchana T. (1970) The Effect of Deep-well pumping on Land Subsidence in Bangkok Area. MEng thesis, Asian Institute of Technology, Bangkok, Thailand.

Premchitt J. (1981) A technique in using integrodifferential equation for model simulation of multiaquifer systems. Water Resources Research, 17, No. 1, 184-193.

RAMNARONG V. (1983) Environmental impacts of heavy groundwater development in Bangkok, Thailand. Proceedings of the International Conference on Groundwater and Management, Sydney, Vol. 2, pp. 345-350.

RAmNARONG V. and BUAPENG S. (1991) Mitigation of groundwater crisis and land subsidence in Bangkok. Journal of Thai Geoscience. 2, 125-137.

Schiffman R. L. (1958) Consolidation of soil under time dependent loading and varying permeability, Proceedings of the Highways Research Board, No. 27, 584-617.

SchiffMAN R. L. (1960) Field application of soil consolidation, time dependent loading and varying permeability. Highways Research Board Bulletin, No. 248

Discussion contributions on this paper should reach the editor by 1 February 2006 